K. A. Novick • P. C. Stoy - G. G. Katul •

D. S. Ellsworth $\cdot$ M. B. S. Siqueira $\cdot$ J. Juang $\cdot$ R. Oren

\title{
Carbon dioxide and water vapor exchange in a warm temperate grassland
}

Received: 24 March 2003 / Accepted: 18 August 2003 / Published online: 20 November 2003

C) Springer-Verlag 2003

\begin{abstract}
Grasslands cover about $40 \%$ of the ice-free global terrestrial surface, but their contribution to local and regional water and carbon fluxes and sensitivity to climatic perturbations such as drought remains uncertain. Here, we assess the direction and magnitude of net ecosystem carbon exchange (NEE) and its components, ecosystem carbon assimilation $\left(A_{\mathrm{c}}\right)$ and ecosystem respiration $\left(R_{\mathrm{E}}\right)$, in a southeastern United States grassland ecosystem subject to periodic drought and harvest using a combination of eddy-covariance measurements and model calculations. We modeled $A_{\mathrm{c}}$ and evapotranspiration (ET) using a bigleaf canopy scheme in conjunction with ecophysiological and radiative transfer principles, and applied the model to assess the sensitivity of NEE and ET to soil moisture dynamics and rapid excursions in leaf area index (LAI) following grass harvesting. Model results closely match eddy-covariance flux estimations on daily, and longer, time steps. Both model calculations and eddy-covariance estimates suggest that the grassland became a net source of carbon to the atmosphere immediately following the harvest, but a rapid recovery in LAI maintained a marginal carbon sink during summer. However, when integrated over the year, this grassland ecosystem was a net $\mathrm{C}$ source ( $97 \mathrm{~g} \mathrm{C} \mathrm{m}^{-2} \mathrm{a}^{-1}$ ) due to a minor imbalance between large
\end{abstract}

\author{
K. A. Novick · G. G. Katul · M. B. S. Siqueira \\ Department of Civil and Environmental Engineering, Duke \\ University, \\ Box 90329 Durham, North Carolina, USA \\ P. C. Stoy $(\bowtie) \cdot$ G. G. Katul · M. B. S. Siqueira · J. Juang · \\ R. Oren \\ Nicholas School of the Environment and Earth Sciences, Duke \\ University, \\ Box 90328 Durham, NC 27708-0328, USA \\ e-mail: pcs3@duke.edu \\ Tel.: +1-919-6138120 \\ Fax: +1-919-6848741 \\ D. S. Ellsworth \\ School of Natural Resources and Environment, University of \\ Michigan, \\ 430 E. University Ave. \\ Ann Arbor, Michigan, USA
}

$A_{\mathrm{c}}\left(-1,202 \mathrm{~g} \mathrm{C} \mathrm{m}^{-2} \mathrm{a}^{-1}\right)$ and $R_{\mathrm{E}}\left(1,299 \mathrm{~g} \mathrm{C} \mathrm{m}^{-2} \mathrm{a}^{-1}\right)$ fluxes. Mild drought conditions during the measurement period resulted in many instances of low soil moisture $\left(\theta<0.2 \mathrm{~m}^{3} \mathrm{~m}^{-3}\right)$, which influenced $A_{\mathrm{c}}$ and thereby NEE by decreasing stomatal conductance. For this experiment, low $\theta$ had minor impact on $R_{\mathrm{E}}$. Thus, stomatal limitations to $A_{\mathrm{c}}$ were the primary reason that this grassland was a net $\mathrm{C}$ source. In the absence of soil moisture limitations, model calculations suggest a net $\mathrm{C}$ sink of $-65 \mathrm{~g} \mathrm{C} \mathrm{m}^{-2} \mathrm{a}^{-1}$ assuming the LAI dynamics and physiological properties are unaltered. These results, and the results of other studies, suggest that perturbations to the hydrologic cycle are key determinants of $\mathrm{C}$ cycling in grassland ecosystems.

Keywords Net ecosystem exchange $\cdot$ Ecosystem modeling $\cdot$ Evapotranspiration $\cdot$ Eddy-covariance Grassland ecosystems

\section{Introduction}

Understanding the mechanisms that control ecosystem carbon balance is a critical research priority given the sensitivity of the carbon cycle to the biogeochemical and hydrologic cycles of the terrestrial biosphere (Sarmiento and Wofsy 1999; Houghton et al. 2001). Long-term $\mathrm{CO}_{2}$ and $\mathrm{H}_{2} \mathrm{O}$ flux monitoring initiatives such as FLUXNET have arisen to understand how environmental variables drive carbon cycling in ecosystems across the globe (Baldocchi et al. 2001). However, most long-term $\mathrm{CO}_{2}$ flux research focuses on forests, with a consequent shortage of $\mathrm{CO}_{2}$ flux data for grassland ecosystems worldwide (Falge et al. 2001a, 2001b; Valentini et al. 2000; Baldocchi et al. 2001). In addition, many studies and summaries of grassland $\mathrm{C}$ dynamics historically concentrated on net primary productivity (NPP), not on net ecosystem exchange of carbon (NEE) (e.g., Long et al. 1992; Scurlock et al. 2002).

Forested ecosystems in the southeastern United States are characterized by long, warm, and mesic growing seasons that favor high carbon assimilation rates (Clark et 
al. 1999; Baldocchi and Wilson 2001; Oren et al. 2001; Wilson and Baldocchi 2001). The grassland under study here is typical of abandoned agricultural sites in the southeastern United States, and is warmer and wetter than most grassland ecosystems. Grassland ecosystems comprise approximately $40.5 \%$ of the Earth's terrestrial land area, excluding areas of permanent ice (White et al. 2000). Large uncertainties remain in resolving whether grassland ecosystems function as $\mathrm{CO}_{2}$ sources or sinks (Ojima et al. 1993; Parton et al. 1993; Baldocchi et al. 2001): annual grassland NEE estimates based on eddy-covariance measurements and Bowen Ratio Energy Balance techniques vary from a net source of $+400 \mathrm{~g} \mathrm{C} \mathrm{m}^{-2} \mathrm{a}^{-1}$ to a net sink of $-800 \mathrm{~g} \mathrm{C} \mathrm{m}^{-2} \mathrm{a}^{-1}$ (Table 1). This uncertainty is primarily attributable to the sensitivity of grasslands to interannual variability in climate and associated biomass dynamics (Knapp and Smith 2001; Meyers 2001; Flanagan et al. 2002; Jackson et al. 2002; Scurlock et al. 2002), and incomplete understanding of the regulation of ecosystem respiration (Raich and Potter 1995; Knapp et al. 1998; Wagai et al. 1998).

The objective of this investigation is to assess the magnitude and direction of NEE and its components $\left(A_{\mathrm{c}}\right.$ and $\left.R_{\mathrm{E}}\right)$ in a southeastern United States warm-temperate grassland ecosystem, and to assess NEE and ET responses to episodic droughts and harvests. To this end, we use a big-leaf process-based model that combines ecophysiological and radiative transfer principles. The model is calibrated with both leaf-level gas exchange and ecosystem-level eddy-covariance measurements from an abandoned agricultural field at the Duke Forest $\mathrm{C}-\mathrm{H}_{2} \mathrm{O}$ Research Site near Durham, N. C. The model is then used to conduct a sensitivity analysis to drought and leaf area perturbations, and results are evaluated with respect to grassland water and carbon balance studies to date.

\section{Methods}

Model

Net ecosystem carbon exchange (NEE) is defined as the difference between ecosystem carbon assimilation $\left(A_{\mathrm{c}}\right)$ and ecosystem respiration $\left(R_{\mathrm{E}}\right)$.

$\mathrm{NEE}=A_{\mathrm{c}}+R_{\mathrm{E}}$

We adopt the micrometeorological convention in which fluxes from the biosphere to the atmosphere are positive. We employed the biochemical photosynthesis model of Farquhar et al. (1980) as given in Appendix A to compute leaf-level assimilation $\left(A_{\mathrm{n}}\right)$ for $\mathrm{C}_{3}$ grass species, and coupled $A_{\mathrm{n}}$ to a big-leaf canopy scheme (Kim and Verma 1991) to scale from leaf to canopy. Grassland foliage is concentrated in short canopy heights, and the big-leaf approximation can be used to scale photosynthesis from leaf to canopy to a first approximation (Kim and Verma 1991) using:

$A_{\mathrm{c}} \approx A_{\mathrm{n}} \times\left(f_{\mathrm{LAI}} \times \mathrm{LAI}\right)$

where LAI is leaf area index $\left(\mathrm{m}^{2} \mathrm{~m}^{-2}\right)$ and $f_{\mathrm{LAI}}$ is the fraction of LAI that absorbs incident photosynthetically active radiation (PAR).
Here, $f_{\text {LAI }}$ is modeled after Campbell and Norman (1998):

$f_{\mathrm{LAI}}=\exp \left(-K_{\mathrm{b}}(\psi) \times \mathrm{LAI}\right)$

where $K_{\mathrm{b}}$, the light extinction coefficient, is a function of the sun zenith angle $\psi . K_{\mathrm{b}}$ is estimated from the Campbell and Norman (1998) model with a leaf angle distribution parameter $(x)$ of 0.7 , appropriate for erect grass leaves.

$A_{\mathrm{n}}$ is related to stomatal conductance to $\mathrm{CO}_{2}\left(g_{\mathrm{s}}\right)$ using a variant on Fick's law (e.g., Cowan 1977):

$A_{\mathrm{n}}=g_{\mathrm{s}} \times C_{\mathrm{a}}\left(\frac{C_{\mathrm{i}}}{C_{\mathrm{a}}}-1\right)$

where $C_{\mathrm{i}}$ is the $\mathrm{CO}_{2}$ concentration in the intercellular spaces in the leaf and $C_{\mathrm{a}}$ is the ambient atmospheric $\mathrm{CO}_{2}$ concentration ( $\sim 385 \mathrm{ppm})$. Numerous empirical and semi-empirical models for $g_{\mathrm{s}}$ and bulk canopy conductance $\left(g_{\mathrm{c}}\right)$ have been proposed (e.g. Leuning 1995; Katul et al. 2000), with the simplest being a variant on the Jarvis (1976) model, given by:

$$
\begin{aligned}
g_{\mathrm{c}} & =g_{\text {ref }}(\mathrm{PAR}) \times f_{1}(\mathrm{VPD}) \times f_{2}(\theta) \\
& =\left(f_{\mathrm{LAI}} \mathrm{LAI}\right) \times g_{\mathrm{s}}
\end{aligned}
$$

where $g_{\text {ref }}$ is the conductance at a reference vapor pressure deficit (VPD) of $1 \mathrm{kPa}$ for well-watered conditions (Oren et al. 1999), $f_{1}$ (VPD) is a reduction function for vapor pressure deficit and $f_{2}(\theta)$ is a reduction function for soil moisture. The function $g_{\text {ref }}$ is assumed to vary with PAR and was determined from eddy-covariance measured water vapor flux when $\theta>\theta_{R}$, where $\theta$ is the volumetric root-zone soil moisture content and $\theta_{\mathrm{R}}$ is the soil moisture content at which $g_{\mathrm{c}}$ is limited.

The function $f_{1}$ (VPD) is given by Oren et al. (1999):

$$
f_{1}(\mathrm{VPD})=1-m \times \ln \left(\mathrm{VPD}_{\mathrm{i}}\right)
$$

where $\mathrm{i}$ is PAR level (Appendix B) and the sensitivity parameter $m(\sim 0.5-0.6)$ is determined in Appendix B using the boundary line analysis proposed by Oren et al. (1999).

A standard soil moisture reduction function of the form:

$f_{2}(\theta)= \begin{cases}1 & ; \frac{\theta}{\theta_{\mathrm{R}}}>1 \\ \left(1-\left(\frac{\theta_{\mathrm{R}}-\theta}{\theta_{\mathrm{R}}}\right)^{\nu}\right) & ; \frac{\theta}{\theta_{\mathrm{R}}} \leq 1\end{cases}$

was chosen to account for drought effects on canopy conductance (Campbell and Norman 1998). Following nonlinear optimization using the Gauss-Newton algorithm (Dennis 1977), $\nu=0.6$ and $\theta_{\mathrm{R}}=0.20$. The $\theta_{\mathrm{R}}$ is consistent with an earlier modeling study by Lai and Katul (2000) in which actual and potential evapotranspiration were shown to diverge at $\theta_{\mathrm{R}}=0.19$ for the same grassland.

To measure and model night-time respiration, we used a different approach than the standard methodology of only accepting data if the friction velocity $\left(u_{*}\right)$ exceeds a certain threshold, $u_{*}$. Commonly, $u_{* \mathrm{t}}$ is taken to be between 0.1 and $0.2 \mathrm{~m} \mathrm{~s}^{-1}$ (Goulden et al. 1996; Aubinet et al. 2000; Barford et al. 2001). Our respiration model is based on night-time $\mathrm{CO}_{2}$ eddy-covariance measurements collected for both $u_{*}>0.12 \mathrm{~m} \mathrm{~s}^{-1}$ and for near-neutral atmospheric stability conditions $(|(z-d) / L|<0.1$, see Appendix C). Here, $z$ is instrument height $(3.0 \mathrm{~m}), L$ is the Obukhov length (Brutsaert $1982 \mathrm{p} 65)$, and $h$ and $d$ are the mean canopy height and zero-plane displacement $(\sim 2 / 3$ $h)$, respectively. The addition of the atmospheric stability constraint to the usual night-time friction velocity threshold ensures that the flow is a fully developed turbulent flow that is near-neutral and not "contaminated" by large-scale phenomena such as gravity waves or meandering, and is critical for constraining the night-time flux footprint (see Appendix C). In fact, from Appendix C, accepting $u_{*_{t}}$ as the only threshold with no atmospheric stability consideration can 


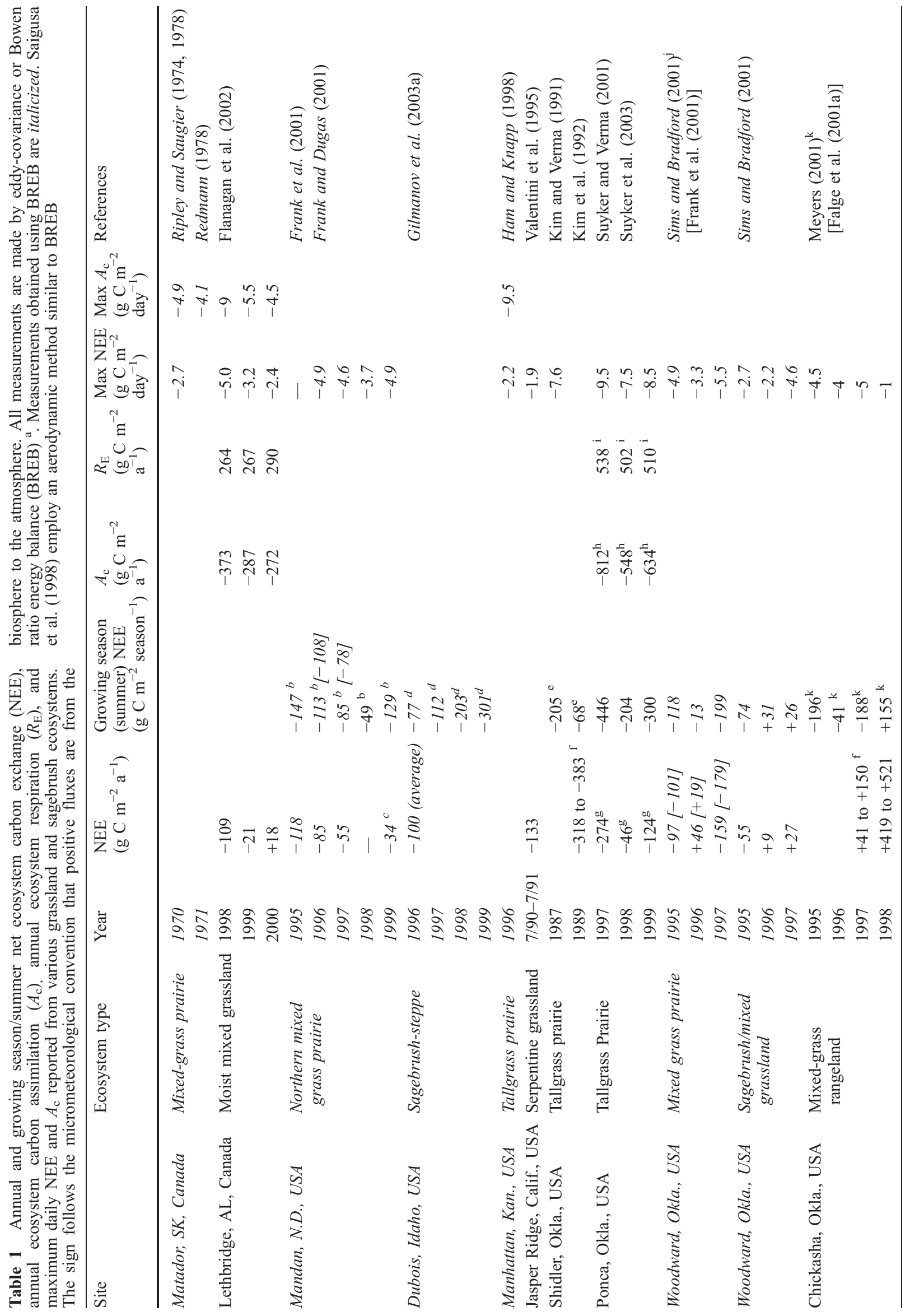




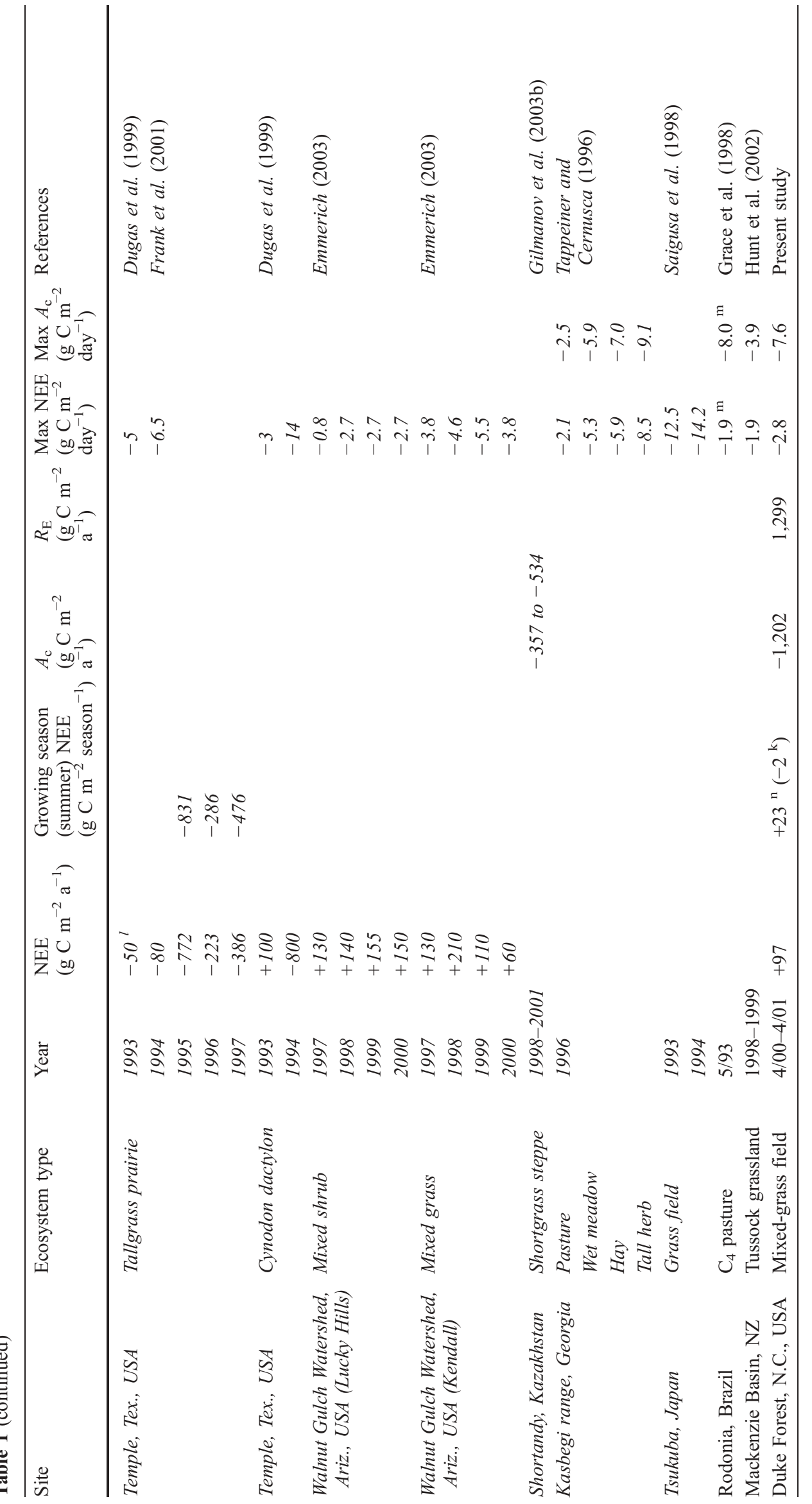




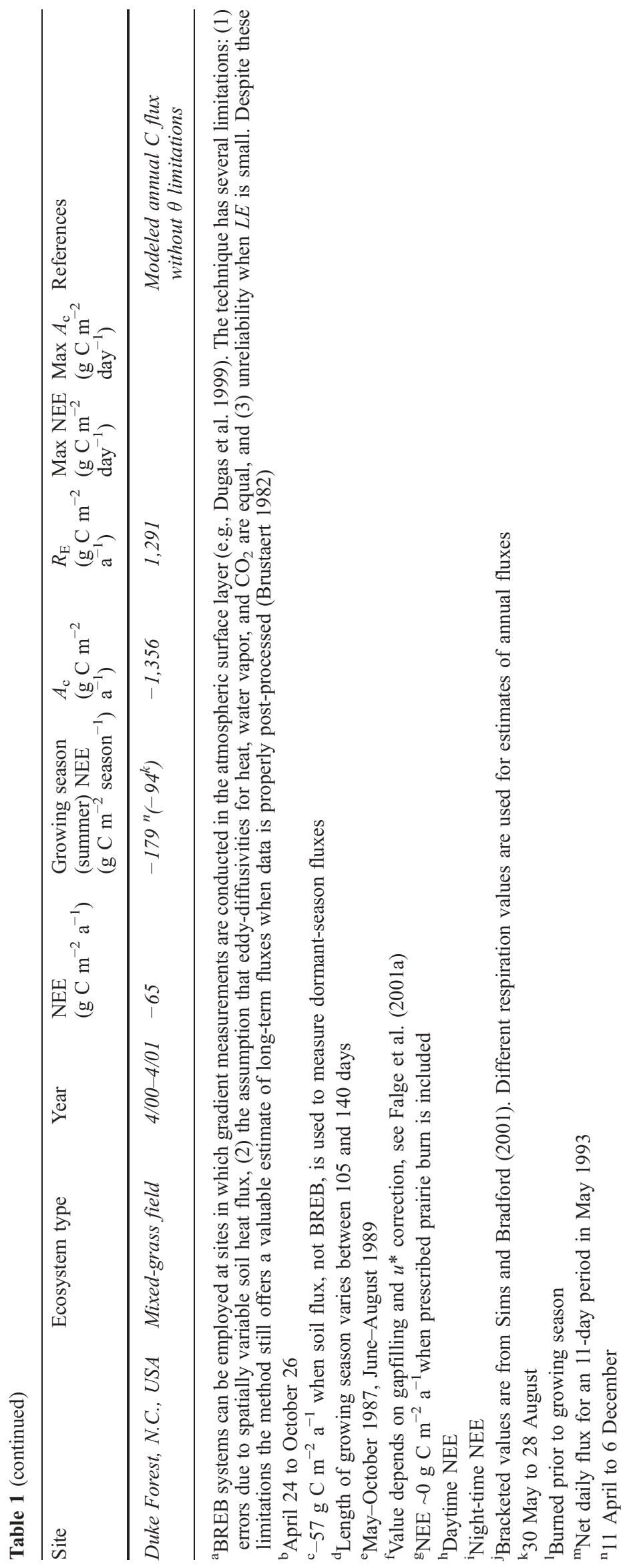


give flux source areas in excess of $5 \mathrm{~km}$, an order of magnitude larger than the dimensions of our field.

Ecosystem respiration was modeled as a function of temperature with the widely used van't Hoff (1898) equation:

$R_{\mathrm{E}}=\left(R_{10}\right)\left(Q_{10}\right)^{(T-10) / 10}$

where $R_{10}$ is the reference respiration rate at $10^{\circ} \mathrm{C}$ and $Q_{10}$ is the ecosystem respiration sensitivity to temperature. From regression analysis on night-time fluxes of the entire data set, we computed an effective $Q_{10}$ of 1.55 and $R_{10}$ of $2.54 \mu \mathrm{mol} \mathrm{CO} \mathrm{m}^{-2} \mathrm{~s}^{-1}$. All model parameters are summarized in Table 2 .

Seasonal variations in respiration parameters may be important components of the error in annual $\mathrm{C}$ budget estimates generated from eddy-covariance measurements that Goulden et al. (1996) termed "sampling uncertainty". There is evidence that ecosystem $Q_{10}$ and $R_{10}$ vary throughout the course of a year, but also that single annual respiration parameters may be sufficient to calculate annual $R_{\mathrm{E}}$ estimates (Janssens and Pilegaard 2003). To test this observation using eddy-covariance measurements, we estimate annual fluxes using both annually averaged and seasonally generated $Q_{10}$ and $R_{10}$ parameters (Tables 2,3 ). To quantify respiration parameters that vary throughout the course of the year, $Q_{10}$ and $R_{10}$ are calculated for summer (May-August) and winter (November-February) per unit leaf area, and the actual $Q_{10}$ and $R_{10}$ are generated using a simple interpolation:

$$
\begin{aligned}
Q_{10}= & \left(Q_{10, \mathrm{w}}-Q_{10, \mathrm{~s}}\right) \\
& \times\left(\frac{\mathrm{LAI}-\mathrm{LAI}_{\min }}{\mathrm{LAI}_{\min }-\mathrm{LAI}_{\max }}\right)+Q_{10, \mathrm{w}}
\end{aligned}
$$

where $Q_{10, \mathrm{w}}$ and $Q_{10, \mathrm{~s}}$ are $Q_{10}$ values calculated for winter and summer, respectively, and $\mathrm{LAI}_{\max }$ and $\mathrm{LAI}_{\min }$ are maximum and minimum measured LAI. The interpolation for $R_{10}$ follows the same model.

$R_{\mathrm{E}}$ was unrelated to soil moisture for the mild drought conditions encountered during the measurement period. We tested whether the residuals from equation 8 (i.e., the difference between measured and modeled $R_{\mathrm{E}}$ fluxes) depend on soil moisture and found weak correlation $\left(r^{2}=0.09\right)$. Other studies have also shown an insignificant relationship between respiration and soil moisture (Fang and Moncreiff 2001), and this observation appears to hold for the mild drought encountered here though a stronger dependence on soil moisture may result from more severe droughts.

During the study period, the grass was cut on 29 June 2001, necessitating a dynamic LAI growth model immediately following this perturbation. We chose a mathematical model whose canonical form resembles a logistic growth equation. Such a model is approximated by a sequence of cubic splines to the four discrete LAI measurements (Fig. 1). The cubic spline technique to fit discrete data is described in Press et al. (1992 p108).

To calibrate our conductance model and to explore water fluxes from the canopy, we modeled latent heat exchange (LE) as:

$\mathrm{LE}=L_{\mathrm{v}} \times 1.6 g_{\mathrm{c}} \times \mathrm{VPD}$

where $L_{\mathrm{v}}$ is the latent heat of vaporization of water, and the 1.6 factor is needed to correct canopy conductance for differences in binary diffusivity between $\mathrm{CO}_{2}$ and $\mathrm{H}_{2} \mathrm{O}$.

In the analysis, $A_{\mathrm{c}}$ is computed as the difference between NEE and modeled $R_{\mathrm{E}}$ for daytime runs. $R_{\mathrm{E}}$ is the eddy-covariancemeasured NEE value at night when $u_{*}>0.12 \mathrm{~m} \mathrm{~s}^{-1}$ and $|(z-d) / L|<0.1$, and is modeled $R_{\mathrm{E}}$ at all other times. Daily, seasonal, and annual sums of fluxes are called "estimates" because they depend on both directly measured fluxes and model results (e.g., equation 8) that fill gaps in the data record.

Table 2 Model parameters were measured via gas exchange or estimated from eddy-covariance through nonlinear optimization or

\begin{tabular}{|c|c|c|c|c|}
\hline Parameter & Description & Value & Units & Source \\
\hline \multicolumn{5}{|c|}{ Photosynthesis } \\
\hline$V c_{\max }$ & Maximum Rubisco carboxylation capacity & 81.3 & $\mu \mathrm{mol} \mathrm{CO} \mathrm{Cm}^{-2} \mathrm{~s}^{-1}$ & $\begin{array}{l}\text { Gas exhange measurements taken during the } \\
\text { growing season }\end{array}$ \\
\hline$\alpha$ & Leaf absorptivity for PAR & 0.83 & $\mathrm{~mol} \mathrm{~mol}^{-1}$ & Campbell and Norman (1998) \\
\hline$e_{\mathrm{m}}$ & Maximum quantum efficiency & 0.08 & - & Campbell and Norman (1998) \\
\hline$C_{\mathrm{i}} / C_{\mathrm{a}}$ & Mean ratio of intercellular to ambient $\mathrm{CO}_{2}$ & 0.75 & - & $\begin{array}{l}\text { Gas exhange measurements taken during the } \\
\text { growing season }\end{array}$ \\
\hline$\left[\mathrm{O}_{2}\right]$ & Oxygen mole fraction $\left(\mathrm{mmol} \mathrm{mol}^{-1}\right)$ & 210 & $\mathrm{mmol} \mathrm{mol}^{-1}$ & Campbell and Norman (1998) \\
\hline$\tau$ & $\begin{array}{l}\text { Ratio describing } \mathrm{CO}_{2} / \mathrm{O}_{2} \text { partitioning } \\
\text { by Rubisco }\end{array}$ & 1.3 & - & Campbell and Norman (1998) \\
\hline$K_{\mathrm{c} 25}$ & Michaelis constant for $\mathrm{CO}_{2}$ fixation & 300 & $\mu \mathrm{mol} \mathrm{mol}{ }^{-1}$ & Campbell and Norman (1998) \\
\hline$\gamma$ & $K_{\mathrm{c}}$ parameter & 0.074 & - & \\
\hline$K_{\mathrm{O} 2,25}$ & Michaelis constant for $\mathrm{O}_{2}$ inhibition & 300 & $\mathrm{mmol} \mathrm{mol}{ }^{-1}$ & Campbell and Norman (1998) \\
\hline$\gamma$ & $K_{\mathrm{O} 2}$ parameter & 0.018 & - & \\
\hline$x$ & Leaf angle distribution parameter & 0.7 & - & Campbell and Norman (1998) \\
\hline \multicolumn{5}{|c|}{ Canopy conductance } \\
\hline$\nu$ & Soil parameter & 0.6 & - & Nonlinear optimization \\
\hline$\theta_{\mathrm{R}}$ & Moisture content below which $g_{\mathrm{c}}$ is reduced & 0.2 & $\mathrm{~m}^{3} \mathrm{~m}^{-3}$ & Nonlinear optimization and Lai and Katul (2000) \\
\hline$m$ & Sensitivity of canopy conductance to VPD & 0.6 & - & $\begin{array}{l}\text { Eddy-covariance measured } L E \text { using BLA. } \\
\text { Oren et al. (1999) }\end{array}$ \\
\hline \multicolumn{5}{|l|}{ Respiration } \\
\hline$R_{10}$ & Scale parameter & 2.54 & $\mu \mathrm{mol} \mathrm{m} \mathrm{s}^{-1}$ & $\begin{array}{l}\text { Eddy-covariance measurements for } \\
u_{*}>0.12 \mathrm{~m} \mathrm{~s}^{-1} \text { and }|(z-d) / L|<0.1\end{array}$ \\
\hline$Q_{10}$ & Slope parameter & 1.55 & - & Same as $R_{10}$ \\
\hline
\end{tabular}
boundary-line analysis (BLA). Parameters not directly measured are taken from the cited literature 
Table 3 Modeled and estimated annual carbon and water budgets in a southeastern United States grassland. 'Modeled—no drought' refers to the modeling analysis where soil moisture was parameterized to have no influence on stomatal conductance

\begin{tabular}{|c|c|c|c|c|c|c|}
\hline Variable & $\begin{array}{l}\text { Estimated: single annual } \\
\text { respiration paramters }\end{array}$ & $\begin{array}{l}\text { Estimated: seasonal } \\
\text { respiration paramters }\end{array}$ & Modeled & $\begin{array}{l}\text { Modeled- } \\
\text { no drought }\end{array}$ & $\begin{array}{l}\text { Modeled- } \\
\text { drought, no harvest }\end{array}$ & $\begin{array}{l}\text { Modeled-no drought, } \\
\text { no harvest }\end{array}$ \\
\hline $\operatorname{ET}\left(\mathrm{mm} \mathrm{a}^{-1}\right)$ & 568 & 568 & 547 & 738 & 570 & 767 \\
\hline$A_{\mathrm{c}}\left(\mathrm{g} \mathrm{C} \mathrm{m}^{-2} \mathrm{a}^{-1}\right)$ & $-1,202$ & $-1,304$ & $-1,207$ & $-1,356$ & $-1,230$ & $-1,381$ \\
\hline$R_{\mathrm{E}}\left(\mathrm{g} \mathrm{C} \mathrm{m}^{-2} \mathrm{a}^{-1}\right)$ & 1,299 & 1,433 & 1,291 & 1,291 & 1,291 & 1,291 \\
\hline $\operatorname{NEE}\left(\mathrm{g} \mathrm{C} \mathrm{m}^{-2} \mathrm{a}^{-1}\right)$ & 97 & 129 & 84 & -65 & 61 & -90 \\
\hline
\end{tabular}

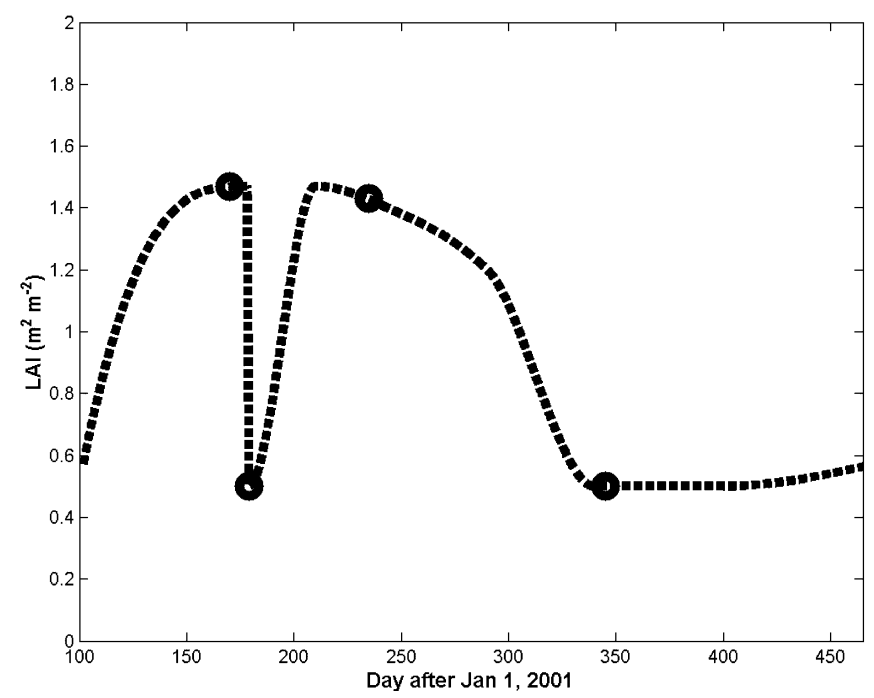

Fig. 1 Modeled leaf area index (LAI) from 11 April 2001 to 11 April 2002. LAI measurements are shown as large circles

\section{Measurements}

The experimental site is a grass-covered field in the Blackwood Division of the Duke Forest in Orange County, near Durham, North Carolina $\left(35.971^{\circ} \mathrm{N}, 79.09^{\circ} \mathrm{W}\right.$, elevation $\left.163 \mathrm{~m}\right)$. The long-term mean annual temperature and precipitation are $15.5^{\circ} \mathrm{C}$ and $1,145 \mathrm{~mm}$, respectively. The field is approximately $480 \times 305 \mathrm{~m}$, dominated by the $\mathrm{C}_{3}$ grass Festuca arundinaria Shreb., and surrounded by loblolly pine (Pinus taeda L.) forest. The vegetation includes minor components of $\mathrm{C}_{3}$ herbs and the $\mathrm{C}_{4}$ grass Schizachyrium scoparium (Michx.) Nash, not considered here. The site was burned in 1979 and is mowed annually during the summer for hay according to local practices. For this investigation, we consider data collected between 11 April 2001 and 11 April 2002.

Scalar fluxes were measured using an eddy-covariance system comprised of a triaxial sonic anemometer (CSAT3, Campbell Scientific, Logan, Utah) and an open-path gas analyzer (LI-7500, Li-Cor, Lincoln, Neb.), positioned $3.0 \mathrm{~m}$ above the canopy. The gas analyzer was tilted $35^{\circ}$ from the vertical to avoid direct sunlight contamination and to minimize water accumulation on the absorbing lens surface. The LI-7500 was separated from the CSAT3 by $10 \mathrm{~cm}$, a distance comparable to the sonic path averaging length. The time series of all three velocity components, temperature, and scalar concentrations were sampled using a 23X data logger (Campbell Scientific, Logan, Utah) at $10 \mathrm{~Hz}$. All covariances were then computed over a 30-minute period using the procedures described in Katul et al. (1997). The Webb-Pearman-Leuning correction (Webb et al. 1980) was subsequently applied to the computed scalar covariances.

The tower was located in the middle of the field with approximately $250 \mathrm{~m}$ fetch to the southwest, the predominant direction of flow during summer. The peak of the source weight function $\left(x_{\mathrm{p}}\right)$ describes the peak of the maximum source area that contributes to fluxes, and was estimated using the footprint model in Hsieh et al. (2000) to be smaller than $150 \mathrm{~m}$ (at $z=3 \mathrm{~m}$ ) for most stability runs, except for stable conditions (Appendix C). The source weight function describes the relative scalar flux contribution to a measurement location for various scalar source areas upwind. The term "footprint" is the distance at which $90 \%$ of the scalar flux contributes to the measurement location as determined from the integrated source weight function. $R_{\mathrm{E}}$ data collected during stable atmospheric conditions at night or when $x_{\mathrm{p}}$ exceeded the size of the field were discarded and replaced with the output of the $Q_{10}$ respiration function.

PAR, air temperature $\left(T_{\mathrm{a}}\right)$, relative air humidity $(\mathrm{RH})$, net radiation $\left(R_{\text {net }}\right)$ and $\theta$ were sampled every second and averaged every half-hour. $R_{\text {net }}$ was measured with a Fritschen-type net radiometer (Q7, REBS, Seattle, WA) and incident PAR with a quantum sensor (LI-190SA Li-Cor, Lincoln, NE). $T_{\mathrm{a}}$ and RH were measured with a HMP35C temperature/RH probe (Campbell Scientific, Logan, Utah). $\theta$ was measured using ThetaProbe soil moisture sensors Type ML1 (Delta-T Devices, Cambridge, UK) positioned at $10 \mathrm{~cm}$ and $25 \mathrm{~cm}$ depths at six locations north and south of the eddy-covariance tower, and at a depth of $10 \mathrm{~cm}$ at locations east and west of the tower.

Gas exchange measurements were used to estimate the apparent maximum rubisco carboxylation capacity $\left(V c_{\max }\right)$ and were performed in May, June and August 2001 using an open-flow LI6400 portable photosynthesis system (Li-Cor, Lincoln, Neb.). For leaf-level photosynthesis, $V c_{\max }$ was directly fitted to in situ responses of $A_{\mathrm{n}}$ to $\mathrm{CO}_{2}$ supply under controlled conditions (following the approach of Medlyn et al. 2002). The response of $A_{\mathrm{n}}$ to intercellular $\mathrm{CO}_{2}$ concentration $\left(C_{\mathrm{i}}\right)$ was measured in the field within $50 \mathrm{~m}$ of the tower in mid-morning on sunny days by controlling chamber conditions to light saturation $(1,800 \mu \mathrm{mol} \mathrm{m}$ $\mathrm{s}^{-1}$ quantum flux density) and $29-32^{\circ} \mathrm{C}$ leaf temperature with VPD $=1.8 \mathrm{kPa}$ for $9-10$ different $C_{\mathrm{i}}$ steps. $V c_{\max }$ was then fitted to the initial slope comprising at least five $C_{\mathrm{i}}$ levels $<250 \mathrm{\mu mol} \mathrm{mol}^{-1}$, with $r^{2}$ exceeding 98\% (Table 2).

We calculated LAI from PAR transmission data collected along three $50 \mathrm{~m}$ transects in a $120^{\circ}$ swath to the south of the eddycovariance tower. The PAR transmission data were measured with an 80-sensor series of quantum sensors (AccuPAR model PAR-80 Ceptometer, Decagon Instruments, Pullman, Wash.) and used to calculate gap fractions, which were inverted to provide LAI estimates after Norman and Campbell (1989). Time series of environmental drivers for the measurement period 11 April 2001 to 11 April 2002 are presented in Fig. 2.

The eddy-covariance methodology is prone to missing data points that can occur due to precipitation, extreme weather events, sensor malfunction, or power outage. Raw flux data coverage for this site over the period of examination (11 April 2001 to 11 April 2002) was $92.9 \%$ (16,281 of 17,520 potential data points). After filtering out night-time $\mathrm{CO}_{2}$ flux data using the criteria in Appendix C, $45.1 \%$ of potential $\mathrm{CO}_{2}$ flux data points remain. A variety of methods exist to 'gapfill' missing $\mathrm{CO}_{2}$ and LE data, as summarized in Falge et al. (2001a, 2001b). NEE data gaps when PAR exceeded the light compensation point $\left(213 \mu \mathrm{mol}\right.$ photons $\left.\mathrm{m}^{-2} \mathrm{~s}^{-1}\right)$ were filled by fitting a nonlinear regression of measured $\mathrm{CO}_{2}$ flux about PAR and replacing missing data points with the results of the regression (Fig. 3a). NEE data gaps for night-time and low PAR periods were filled using the $Q_{10}$ respiration equation. Gaps in the LE record were 
Fig. 2 Time series of maximum daily measurements for key ecophysiological drivers from 11 April 2001 to 11 April 2002: a photosynthetically active radiation (PAR), b $R_{\text {net }}$, c maximum and minimum $T_{\mathrm{a}}$, d vapor pressure deficit, and $\mathbf{e}$ volumetric soil moisture content $(\theta)$. Measured data are black points; gray points indicate gapfilled data. The point at which soil moisture limits conductance $\left(\theta=0.2 \mathrm{~m}^{3} \mathrm{~m}^{-3}\right)$ is indicated by a dashed line
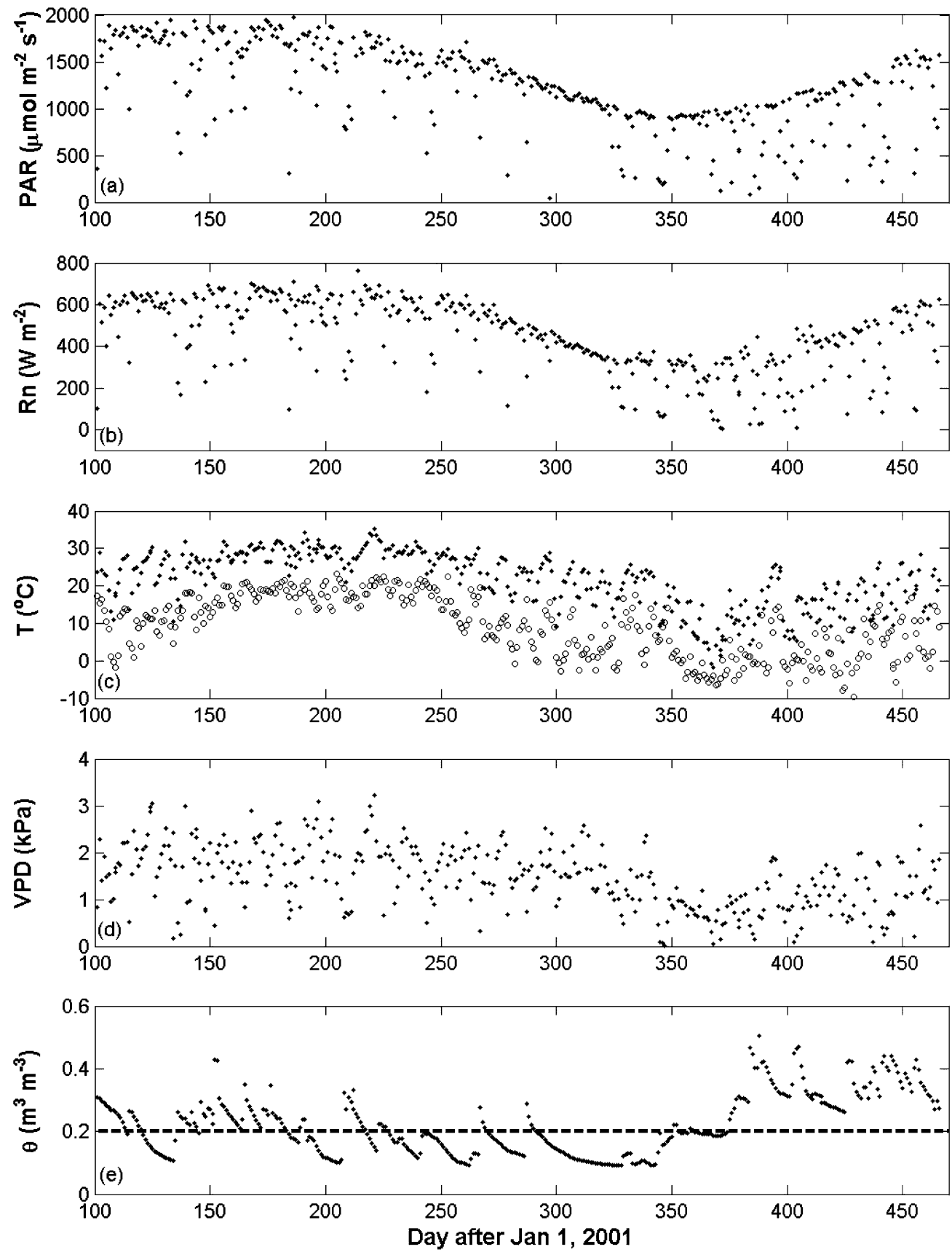

filled by fitting a linear regression of LE about $R_{\text {net }}$ (Fig. 3b), and replacing missing data points with the results of the regression (Brutsaert and Sugita 1992).

Temporal data coverage for PAR was $87.5 \%$, for $R_{\text {net }} 87.0 \%$, for $\mathrm{RH}$ and $T_{\mathrm{a}} 80.5 \%$ and for $\theta 67.6 \%$. To gapfill missing environmental data, a linear relationship was derived between measured data points at the grass site and adjacent pine and hardwood eddy-covariance tower sites under identical climatic and edaphic conditions. Missing data were gapfilled with the results of the regression.

\section{Results and discussion}

To address the study objectives, we first discuss estimated and modeled ET and NEE and compare these results with other studies. We then proceed to assess the impact of harvesting on ET and NEE and summarize the contributions of this study to current understanding of grassland water and carbon cycling.

\section{Evapotranspiration}

Maximum estimated daily evapotranspiration (ET, $4.1 \mathrm{~mm}$ day ${ }^{-1}$ ) is within the range of values estimated for other grasslands based on eddy-covariance, which range from $\sim 3 \mathrm{~mm}$ day $^{-1}$ to $5.5 \mathrm{~mm} \mathrm{day}^{-1}$ (Ripley and Saugier 1978; Meyers 2001; Dugas et al. 1999; Hunt et al. 2002; Wever et al. 2002). Values estimated by other methods range from $4.2 \mathrm{~mm}$ day $^{-1}$ to $6.2 \mathrm{~mm} \mathrm{day}^{-1}$ as summarized by Kelliher 
Fig. 3 a The relationship between net ecosystem carbon exchange (NEE) and PAR for the one-year measurement record. The solid nonlinear regression line is used to estimate NEE for PAR above the C compensation point $\left(\mathrm{PAR}=213 \mu \mathrm{mol} \mathrm{m} \mathrm{m}^{-2} \mathrm{~s}^{-1}\right.$ ) for gaps in the measurement record. b Latent heat exchange (LE) plotted against net radiation $\left(R_{\text {net }}\right)$. The solid linear regression line is used to estimate LE for gaps in the measurement record
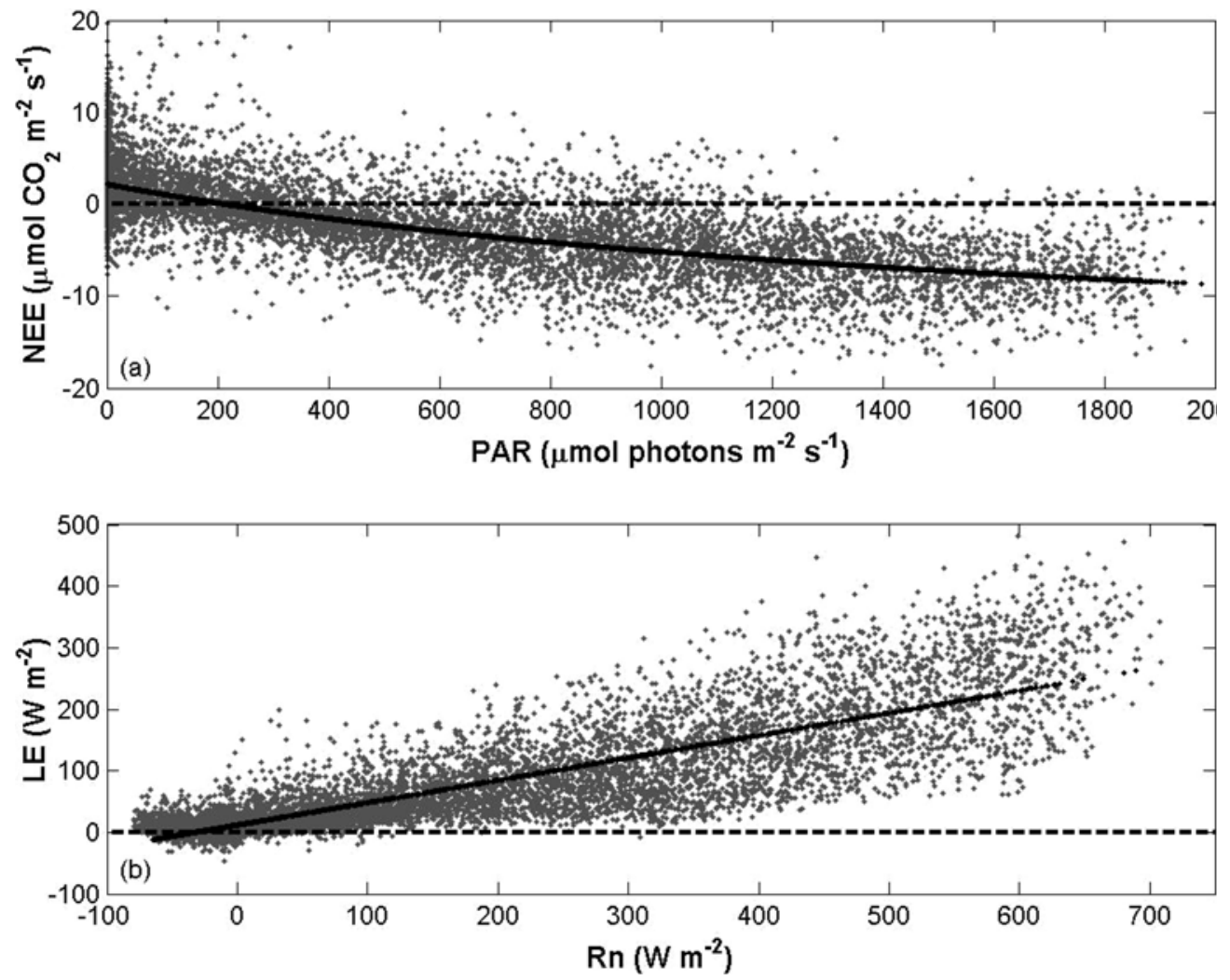

et al. (1993). We repeated the model analysis assuming that soil moisture does not limit conductance for the entire record, yet retaining the same $T_{\mathrm{a}}$ and VPD for a 'droughtfree' scenario. In the absence of soil moisture limitations, modeled maximum daily ET is $5.3 \mathrm{~mm}$, near the maximum of eddy-covariance estimated values for grasses (5.5 mm in Dugas et al. 1999).

Total summer evapotranspiration $\left[\mathrm{ET}_{\mathrm{s}}\right.$, for day of year (DOY) 150-240 based on Meyers (2001)] was $239.2 \mathrm{~mm}$. Our value is close to $\mathrm{ET}_{\mathrm{s}}$ over an Oklahoma rangeland during three non-drought seasons (1995-1997), which averaged $253 \mathrm{~mm}$ (Meyers 2001); $\mathrm{ET}_{\mathrm{s}}$ in southeastern United States grassland during a dry year resembled $\mathrm{ET}_{\mathrm{s}}$ during average precipitation years over the United States Great Plains.

Annual precipitation $\left(P_{\mathrm{a}}\right)$ for the measurement period 11 April 2001 to 11 April 2002 was $821.5 \mathrm{~mm}$. This is $72 \%$ of the long-term average of $1,145 \mathrm{~mm}$, indicating mild drought conditions. Annual evapotranspiration $\left(\mathrm{ET}_{\mathrm{a}}\right)$ for the study period was $568 \mathrm{~mm}$, slightly more than modeled $\mathrm{ET}_{\mathrm{a}}$ (547 mm; Fig. 4; Table 3). $\mathrm{ET}_{\mathrm{a}}$ represented $69.1 \%$ of $P_{\mathrm{a}}$, which is intermediate between published $\mathrm{ET}_{\mathrm{a}} / P_{\mathrm{a}}$ for grasslands that range from $<50 \%$ to over $100 \%$ (Meyers 2001; Paz et al. 1996; Bellot et al. 1999; Nouvellon et al. 2000; Everson 2001; Wever et al. 2002). $\mathrm{ET}_{\mathrm{a}} / P_{\mathrm{a}}$ here is consistent with a natural grassland catchment in Natal Drakensberg, South Africa during two low precipitation years $(\sim 70 \%$; Everson 2001$)$, and two mixed-grassland sites in northwestern Spain during a low precipitation year ( $69 \%$; Paz et al. 1996), suggesting similarities in the water balance of warm-temperate/Mediterranean grassland ecosystems during dry years.

Soil moisture limited $g_{\mathrm{c}}$ (meaning $\theta<\theta_{\mathrm{R}}, \theta_{\mathrm{R}}=0.2 \mathrm{~m}^{3} \mathrm{~m}^{-3}$ ) $52 \%$ of the time for the entire year and $66 \%$ of the time during non-winter periods (Figs. 5a, b). We consider nonwinter periods to be DOY $101-340$, when $A_{\mathrm{c}}$ is not seasonally suppressed by dead vegetation. Re-parameterizing the model to simulate the 'drought-free' scenario results in modeled $\mathrm{ET}_{\mathrm{a}}$ of $738 \mathrm{~mm}$ or $\mathrm{ET}_{\mathrm{a}} / P_{\mathrm{a}}$ of $89.9 \%$ (Table 3). The drought-free modeled $\mathrm{ET}_{\mathrm{a}} / P_{\mathrm{a}}$ is consistent

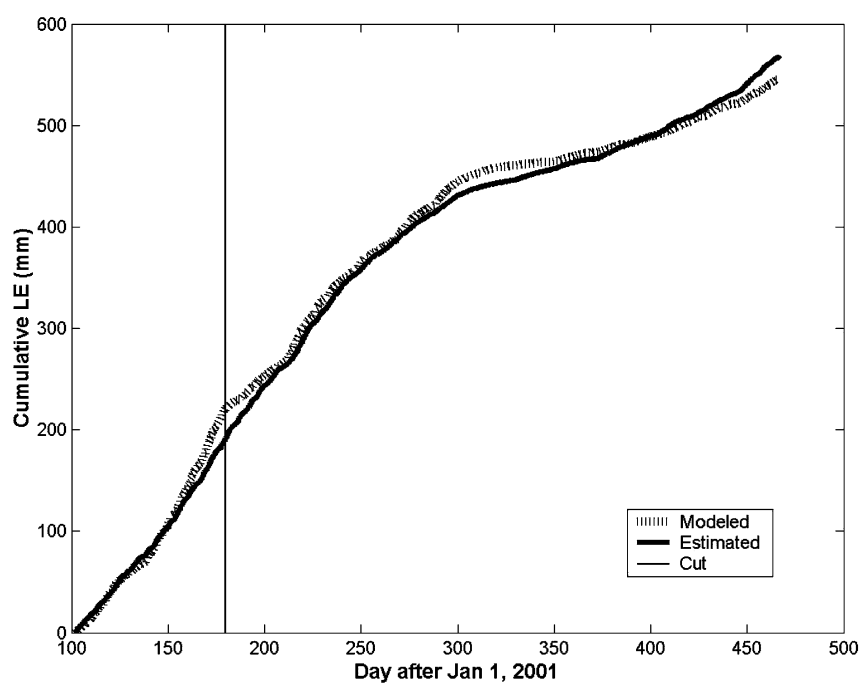

Fig. 4 Estimated and modeled cumulative annual evapotranspiration 
with eddy-covariance and Bowen Ratio Energy Balance studies in grasslands during years with normal to aboveaverage precipitation, although infiltration and soil storage and lower VPD during very wet years decrease this ratio (Meyers 2001; Nouvellon et al. 2000; Wever et al. 2002). Eddy-covariance studies are typically performed on flat terrain. Thus, surface runoff is a small component of the water budget and is not likely to affect the water balance.

\section{Net ecosystem exchange}

Maximum daily $A_{\mathrm{c}}\left(-7.6 \mathrm{~g} \mathrm{C} \mathrm{m}^{-2} \mathrm{day}^{-1}\right)$ is at the upper end of the range of reported values for other grasslands $\left(-2.5 \mathrm{~g} \mathrm{C} \mathrm{m}^{-2} \mathrm{day}^{-1}\right.$ to $-9.1 \mathrm{~g} \mathrm{C} \mathrm{m}^{-2}$ day $^{-1}$; Table 1$)$. Maximum daily NEE was low because of high daily $R_{\mathrm{E}}$ but comparable to other studies with drought impacts (Table 1). High maximum daily $A_{\mathrm{c}}$ and low maximum daily NEE suggest that the magnitude of $R_{\mathrm{E}}$ played a major role in determining the magnitude of net fluxes during both drought and non-drought periods.

Previous studies have demonstrated that $R_{\mathrm{E}}$ decreases with $\theta$ (e.g., Reichstein et al. 2002). However, in our study, the magnitude of $R_{\mathrm{E}}$ was primarily dependent on temperature and was insensitive to $\theta$ for the measurement period, consistent with Fang and Moncreiff (2001). Perhaps a more prolonged drought, especially when coupled with high temperatures, would generate a stronger dependence of $R_{\mathrm{E}}$ on $\theta$.

Positive NEE throughout non-winter periods indicated a net return of $\mathrm{CO}_{2}$ to the atmosphere during this time (Table 1). However, model results show that, in a droughtfree year with no soil moisture limitation on conductance, growing season NEE in our grassland is comparable to other studies (Table 1). NEE is near zero during summer, in contrast to a south-central United States rangeland
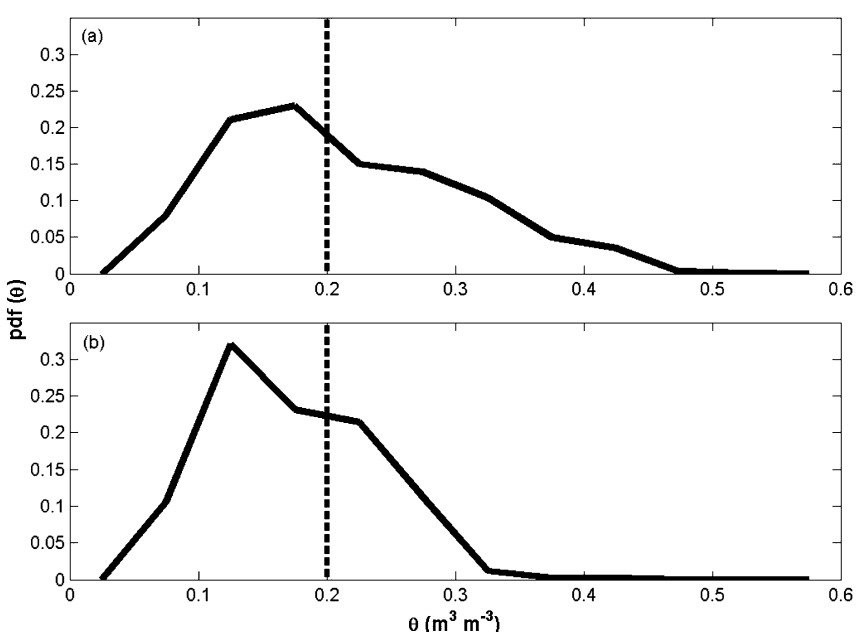

Fig. 5 a Probability density function (pdf) of measured root-zone soil moisture content $(\theta)$ from 11 April 2001 to 10 April 2002. $\theta<\theta_{\mathrm{R}}$ for $52 \%$ of the year. The dotted line indicates the point at which $\theta$ suppresses canopy conductance. $\mathbf{b}$ pdf of soil moisture content $(\theta)$ measurements for non-winter periods (11 April 2001 to 6 December 2002 , defined as the period when $A_{\mathrm{c}}$ is not suppressed). $\theta<\theta_{\mathrm{R}}$ for $66 \%$ of the season which experienced negative net $\mathrm{C}$ fluxes except in the case of severe drought (Meyers 2001). Model results suggest that even in the absence of drought, summer $\mathrm{C}$ fluxes in our grassland only approach $50 \%$ of summer values observed by Meyers (2001) (Table 1), indicating that our grassland is unable to sequester appreciable $\mathrm{C}$ during the summer. In the absence of drought, growing season NEE values approach those of other grasslands not because of a large summertime sink, but because of a longer growing season in the southeastern United States.

Annual NEE (+97 g C m $\left.\mathrm{m}^{-2} \mathrm{a}^{-1}\right)$ was an order of magnitude smaller than estimated annual $A_{\mathrm{c}}(-1,202 \mathrm{~g} \mathrm{C}$ $\left.\mathrm{m}^{-2} \mathrm{a}^{-1}\right)$ and $R_{\mathrm{E}}\left(+1,299 \mathrm{~g} \mathrm{C} \mathrm{m}^{-2} \mathrm{a}^{-1}\right.$; Tables 1, 3; Fig. 6). Annual $A_{\mathrm{c}}$ and $R_{\mathrm{E}}$ were 1.5 times larger and over 2.4 times larger, respectively, than other grasslands (Table 1). These large fluxes reflect the longer growing season in the southeast United States that is warmer and wetter than in the grassland biome. These annual flux estimates were generated using static respiration parameters for the entire year (Tables 2,3 ). The "effective" $Q_{10}$ for the entire year, 1.55 , is at the low end of previously reported values for ecosystems (Raich and Schlesinger 1992; Kirschbaum 2000). $Q_{10}$ estimates are highly dependent on the reference temperature used (Lloyd and Taylor 1994; Tjoelker et al. 2001), whether air or soil temperatures are employed in the calculations, and how the data is pooled or ensembleaveraged.

Flux estimates using respiration parameters that are scaled by leaf area resulted in $A_{\mathrm{c}}=-1,304 \mathrm{~g} \mathrm{C} \mathrm{m}^{-2} \mathrm{a}^{-1}$ (i.e., $102 \mathrm{~g} \mathrm{C} \mathrm{m}^{-2} \mathrm{a}^{-1}$ more negative) and increased $R_{\mathrm{E}}$ to $1,433 \mathrm{~g} \mathrm{C} \mathrm{m}^{-2} \mathrm{a}^{-1}$ (i.e., $134 \mathrm{~g} \mathrm{C} \mathrm{m}^{-2} \mathrm{a}^{-1}$ more positive) for a modified NEE estimate of $129 \mathrm{~g} \mathrm{C} \mathrm{m}^{-2} \mathrm{a}^{-1}$ (Table 3). Despite the large variation in LAI, the annual exchange rates appear to be robust to seasonally dynamic leaf-area scaled respiration parameters. A chamber-based study of belowground respiration by Janssens and Pilegaard (2003) suggested that single annual respiration parameters are adequate for estimating annual belowground respiration. In this eddy-covariance-based study, the magnitude of annual NEE was impacted little by varying respiration parameters throughout the year, although component fluxes $\left(A_{\mathrm{C}}\right.$ and $\left.R_{\mathrm{E}}\right)$ increased in magnitude by over $100 \mathrm{~g}$ $\mathrm{C} \mathrm{m} \mathrm{m}^{-2} \mathrm{a}^{-1}$

Modeled $A_{\mathrm{c}}, R_{\mathrm{E}}$, and NEE with and without soil moisture limitations on $g_{\mathrm{c}}$ are contrasted in Table 3 . Estimated and modeled $A_{\mathrm{c}}, R_{\mathrm{E}}$, and NEE are presented in Fig. 6 as cumulative carbon exchange throughout the measurement period. Root mean square error between modeled and estimated NEE is $0.057 \mathrm{~g} \mathrm{C} \mathrm{m}^{-2} \mathrm{a}^{-1}$. Estimated annual NEE represents a non-trivial $\mathrm{C}$ flux to the atmosphere compared to many other grassland eddycovariance studies (Table 1; but see Falge et al. 2001a). Model calculations suggest that this grassland ecosystem switches from a net annual $\mathrm{C}$ source to a net annual $\mathrm{C}$ sink depending on soil moisture conditions (Table 3). $A_{\mathrm{c}}$ increases when soil moisture limitations are removed due to $g_{\mathrm{c}}$ enhancement, while $R_{\mathrm{E}}$ is insensitive to $\theta$ under mild drought and does not change in the 'drought-free' model analysis since no soil moisture limitation was employed. 
Fig. 6 Estimated and modeled cumulative $A_{\mathrm{n}}$ (negative fluxes), $R_{\mathrm{E}}$ (positive fluxes), and NEE

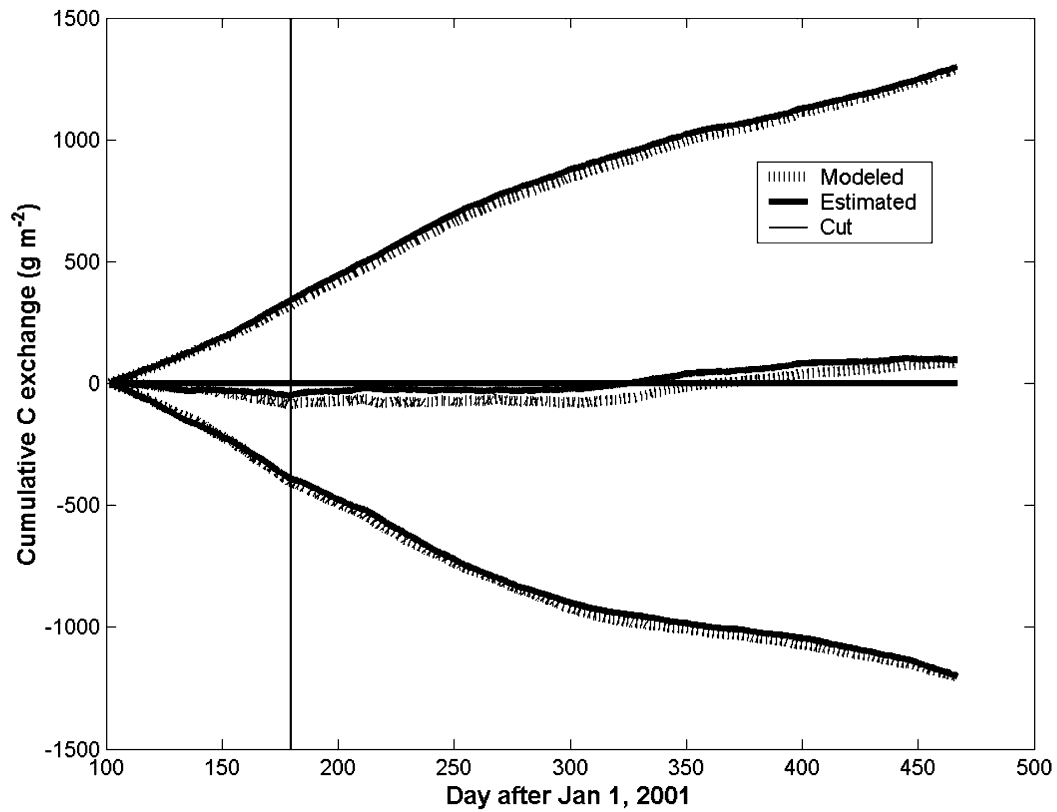

The sign shift observed in drought-free modeled NEE is consistent with results from a northern Great Plains mixed grassland (Flanagan et al. 2002), a southern Great Plains rangeland (Frank et al. 2001), and a southern Great Plains tallgrass prairie (Suyker et al. 2003) (Table 1). In all three studies, the sign shift or increase in NEE sink strength was attributed to an increase in $A_{\mathrm{c}}$ and not a reduction in annual $R_{\mathrm{E}}$, consistent with our model calculations (Table 3 ). These studies, although limited in number, suggest that NEE variability is driven by drought impacts on assimilation and subsequent growth (Knapp and Smith 2001). This contrasts with observations made across a range of European forests, which found that $R_{\mathrm{E}}$, not $A_{\mathrm{c}}$, was the primary contributor of variation in the carbon balance across sites (Valentini et al. 2000).

Positive annual NEE values commonly occur as a result of drought (Table 1), highlighting the strong coupling of the carbon and water cycles in grasslands and further suggesting that perturbations in the hydrologic cycle disrupts the $\mathrm{C}$ balance in grasslands (e.g., Knapp and Smith 2001). However, even in the absence of soil moisture limitations, NEE modeled for our site is low compared to the range of non-drought annual grassland NEE (Tables 1, 3), further suggesting that this southeastern United States grassland is unable to sequester large amounts of carbon under the management protocol (i.e., mowing) required to check woody encroachment.

Our grassland was a net daily $\mathrm{C}$ sink before the harvest on DOY 179 (28 June 2001; Fig. 7), but became a net source immediately thereafter due to the combined impacts of low LAI (Fig. 1) and low $\theta$ (Figs. 2, 5). Unlike Bremer et al. (1998) and Bremer and Ham (2002), we found little reduction in $R_{\mathrm{E}}$ after harvesting. Leaf biomass is a small component of the total respiring biomass, and leaf area is able to quickly respond to mechanical destruction to balance $R_{\mathrm{E}}$ within days (Dugas et al. 1999). Thus, the grassland turned into a net daily sink (on a 24-h basis) as soon as 6 days after harvesting (Fig. 7). These results are similar to a harvested Bermudagrass [Cynodon dactylon (L.)] field (Dugas et al. 1999). In the $C$. dactylon field, negative daily $C$ fluxes were nearly restored 5 days after the cut, and fully restored after 11 days. In both harvesting studies, restoration of negative daily NEE was impelled by the rapid recovery of LAI after the cut (Fig. 1; see also Dugas et al. 1999). However, perturbations on longer time scales, such as drought or nutrient limitation, may have long-lasting effects on LAI and NEE (Meyers 2001; Flanagan et al. 2002).

To evaluate the effect of the management protocol on NEE, we re-parameterized the model to simulate a

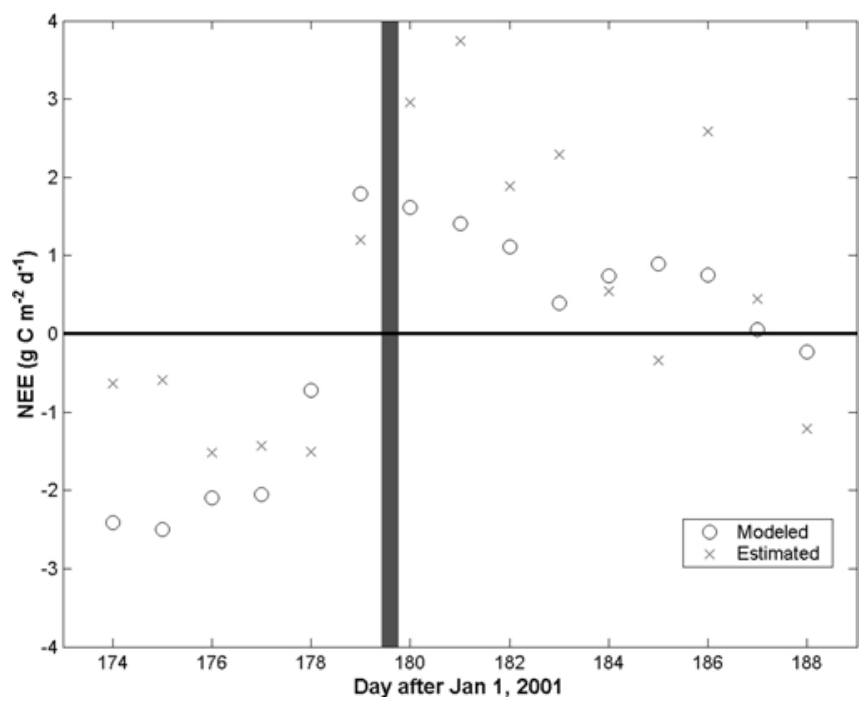

Fig. 7 Comparison between estimated (points) and modeled (circles) daily NEE estimates before and after grass harvesting. The vertical shaded line represents the duration of the tractor harvest and is omitted from the record 
scenario without a harvest. In these simulations, the physiological properties (leaf and respiration parameters) and maximum LAI were not modified after the harvest. Under these idealized conditions, harvesting had a weak and transient effect on NEE fluxes at seasonal and annual time scales, increasing annual NEE by an additional $-24 \mathrm{~g} \mathrm{C} \mathrm{m}^{-2} \mathrm{a}^{-1}$ for both drought and non-drought scenarios (Table 3 ). Thus, the model sensitivity analysis suggests that attempting to manage for $\mathrm{C}$ sequestration by ending the annual harvest over the course of the measurement period would have resulted in little additional $\mathrm{C}$ sequestration. In reality, harvesting impacts other processes, including nutrient content and physiological properties, community composition, and soil compaction and below-ground dynamics, all of which are likely to impact both $A_{\mathrm{c}}$ and $R_{\mathrm{E}}$, but whose effects cannot be assessed with our approach.

It has been suggested that grasslands in warmer and wetter climates will act as a large carbon sink in the future to help mitigate greenhouse warming (Ojima et al. 1993). Although the low estimated and modeled potential C sink strength for this grassland does not support this notion, more long-term monitoring must be undertaken before the role of warm, moist grasslands in $\mathrm{C}$ sequestration is ascertained (e.g., Miranda et al. 1997; Wilsey et al. 2002).

The emerging picture of net ecosystem $\mathrm{C}$ cycling in grassland ecosystems based on this study and similar ones (Table 1) suggests a characteristic NEE that is close to zero - but comprised of large assimilatory and respiratory fluxes - that can readily switch between C source and sink depending primarily on hydrologic perturbations (Kim et al. 1992; Bruce et al. 1999; Frank et al. 2001; Flanagan et al. 2002). A recent study has suggested that future changes in elevated atmospheric $\mathrm{CO}_{2}$ can have an adverse effect on grass ecosystem NPP when combined with other likely global changes including increased $\mathrm{N}$ deposition, temperature, and precipitation (Shaw et al. 2002). Another study has suggested that past increases in atmospheric $\mathrm{CO}_{2}$ have played a more important role in $\mathrm{C}$ sequestration in grasslands than will projected future $\mathrm{CO}_{2}$ enrichment (Gill et al. 2002). Thus, if future increases in atmospheric $\mathrm{CO}_{2}$ may have little effect on future grassland NEE dynamics, the effects of global changes on the variability in the hydrological cycle (Vörösmarty and Sahagian 2000; Jackson et al. 2001; Houghton et al. 2001; Rosenzweig et al. 2002) may be the key driver of future NEE responses in grasslands.

\section{Conclusions}

This study investigated ET and the direction and magnitude of NEE and its components $\left(A_{\mathrm{c}}\right.$ and $\left.R_{\mathrm{E}}\right)$ in a southeastern grassland ecosystem under drought, under simulated drought-free conditions, and with rapid changes in LAI through harvesting.

We found that the relationship between annual ET and annual precipitation was similar to drought-impacted warm-temperate and Mediterranean grasslands, and that 'drought-free' modeled ET resembled North American Great Plains grassland ecosystems studied during nondrought years. The impact of soil moisture limitation on $g_{\mathrm{c}}$ and consequently $A_{\mathrm{c}}$, and not on the variability of $R_{\mathrm{E}}$, was the dominant control on NEE at time scales from days to seasons during a year with mild drought. This contrasts with results from eddy-covariance studies in European forests, which have suggested that variability in $R_{\mathrm{E}}$ exerts dominant control on $\mathrm{C}$ exchange (Valentini et al. 2000). Low soil moisture $(0.1<\theta<0.2)$ reduced stomatal conductance for over half of the year, resulting in a grass ecosystem that was a net source of $\mathrm{CO}_{2}$. In the absence of soil moisture limitations, model calculations suggest that this grassland ecosystem would become a small net annual C sink. The synthesis of results on grassland studies further implies that interannual variability in NEE is large (Table 1), and additional sources of climatic and hydrologic sensitivity should be explored (Knapp and Smith 2001) to improve predictability of grassland ecosystem $\mathrm{C}$ cycling for the future.

Acknowledgements Support was provided by the National Science Foundation (NSF-EAR and NSF-DMS), the Biological and Environmental Research (BER) Program, United States Department of Energy, through the Southeast Regional Center (SERC) of the National Institute for Global Environmental Change (NIGEC), and through the Terrestrial Carbon Processes Program (TCP) and the FACE project. The authors appreciate the contributions of data collection from Ben Poulter and Heather McCarthy. The footprint model of Hsieh et al. (2000) [in Matlab] is available upon request.

\section{Appendix A: leaf-level assimilation model}

According to Farquhar et al. (1980), as later modified by Collatz et al. (1991) and Campbell and Norman (1998), the net photosynthetic rate at the leaf scale depends on light, $\mathrm{CO}_{2}$ concentration, and leaf temperature $\left(T_{1}\right)$ and can be described as:

$A_{\mathrm{n}}=\min \left(\begin{array}{c}J_{\mathrm{E}} \\ J_{\mathrm{C}}\end{array}\right)-R_{\mathrm{d}}$

where $J_{\mathrm{E}}$ and $J_{\mathrm{C}}$ are the assimilation rates restricted by light-driven electron transport processes and ribulose bisphosphate (RuBP) carboxylase-oxygenase activity $(\mathrm{Ru}-$ bisco), respectively, and $R_{\mathrm{d}}$ is dark respiration. For leaflevel processes we adopt the ecophysiological convention of positive fluxes into the leaf. When these fluxes are scaled to the canopy we revert to the micrometeorological convention. $J_{\mathrm{E}}$ is given by:

$J_{\mathrm{E}}=\alpha \times e_{\mathrm{m}} \times Q_{\mathrm{p}} \times \frac{\overline{C_{\mathrm{i}}}-\Gamma_{*}}{\overline{C_{\mathrm{i}}}+2 \Gamma_{*}}$

where $\alpha$ is the leaf absorptivity [not to be confused with the apparent quantum efficiency $\left.\left(\alpha_{\mathrm{a}}\right)\right]$ for photosyntheti- 
cally active radiation (PAR), $e_{\mathrm{m}}$ is the maximum quantum efficiency for leaf $\mathrm{CO}_{2}$ uptake, $Q_{\mathrm{p}}$ is PAR irradiance on the leaf, and $\overline{C_{\mathrm{i}}}$ is the mean intercellular $\mathrm{CO}_{2}$ concentration. The values of all parameters are listed in Table 3 . The photosynthetic $\mathrm{CO}_{2}$ compensation point, $\Gamma_{*}$, is given by:

$$
\Gamma_{*}=\frac{\left[\mathrm{O}_{2}\right]}{2 \tau}
$$

where $\left[\mathrm{O}_{2}\right]$ is the oxygen concentration in air $\left(210 \mathrm{mmol} \mathrm{mol}^{-1}\right)$, and $\tau$ is a ratio of kinetic parameters describing the partitioning of RuBP to the carboxylase or oxygenase reactions of Rubisco. $J_{\mathrm{c}}$ is computed from

$J_{\mathrm{c}}=\frac{V c_{\max }\left(\overline{C_{\mathrm{i}}}-\Gamma_{*}\right)}{\overline{C_{\mathrm{i}}}+K_{\mathrm{c}}\left(1+\left[\mathrm{O}_{2}\right] / K_{\mathrm{O}_{2}}\right)}$

where $V c_{\max }$ is the maximum catalytic capacity of Rubisco per unit leaf area $\left(\mu \mathrm{mol} \mathrm{m} \mathrm{m}^{-2} \mathrm{~s}^{-1}\right.$, and $K_{\mathrm{c}}$ and $K_{\mathrm{O}_{2}}$ are the Michaelis constants for $\mathrm{CO}_{2}$ fixation and $\mathrm{O}_{2}$ inhibition with respect to $\mathrm{CO}_{2}$, respectively. $J_{\mathrm{c}}$ increases linearly with increasing $\overline{C_{\mathrm{i}}}$, but approaches a maximum under a high $\mathrm{CO}_{2}$ concentration state rarely encountered under present conditions, though likely under future climate scenarios.

Temperature dependence of kinetic variables is computed following the equations in Campbell and Norman (1998). Five kinetic parameters are needed to adjust for temperature: $K_{\mathrm{c}}, K_{\mathrm{O}_{2}}, \tau, V c_{\max }$ and $R_{\mathrm{d}}$. For the first two parameters, a modified exponential temperature function of the form:

$k=k_{25} \times \exp \left[\gamma\left(T_{L}-25\right)\right]$

is employed, where $k$ is defined at the leaf surface temperature or $T_{1}, k_{25}$ is the value of the parameter at $25^{\circ} \mathrm{C}$, and $\gamma$ is the temperature coefficient for that parameter. $\tau$ is assumed to be 1.3 .

$V c_{\max }$ and $R_{\mathrm{d}}$ are adjusted by:

$V c_{\max }=\frac{V c_{\max , 25} \exp \left[.088\left(T_{L}-25\right)\right]}{1+\exp \left[.29\left(T_{L}-41\right)\right]}$

and

$R_{\mathrm{d}}=\frac{R_{\mathrm{d}, 25} \exp \left[.069\left(T_{L}-25\right)\right]}{1+\exp \left[1.3\left(T_{L}-55\right)\right]}$

where $V c_{\max , 25}$ and $R_{\mathrm{d}, 25}$ are values of $V c_{\max }$ and $R_{\mathrm{d}}$ at $25^{\circ} \mathrm{C}$, respectively (Campbell and Norman 1998 ).

Following Collatz et al. (1991), the dark respiration rate at $25^{\circ} \mathrm{C}\left(R_{\mathrm{d}, 25}\right)$ can be estimated using
$R_{\mathrm{d}, 25}=0.015 \times V c_{\max , 25}$

\section{Appendix B: the boundary line analysis}

Stomatal conductance was modeled according to Oren et al. (1999), with the parameters $m$ and $g_{\text {ref }}$ generated from a boundary line analysis. The boundary line analysis sorts the measured conductance data into 10 bins characterized by increasing mean light levels. A logarithmic function relating conductance to VPD is generated for each light level $(i)$ using data points falling above the mean plus one standard deviation, after removing outliers at each light level. The function is given by:

$g_{\mathrm{s}, \mathrm{i}}=a_{\mathrm{i}} \times \ln \left(V P D_{\mathrm{i}}\right)+b_{\mathrm{i}}$

where $\mathrm{i}=1-10$ (for ten light levels). The slope $\left(a_{\mathrm{i}}\right)$ and intercept $\left(b_{\mathrm{i}}\right)$ for each $\mathrm{i}$ were computed via regression analysis, and the parameter $m$ is the ratio of these two vectors:

$m=\frac{a}{b}$

in this study, $m=0.64$, which is consistent with the theoretical value of $m=0.6$ from Oren et al. (1999). We use the latter value in the model.

The parameter $g_{\text {ref }}$ is a light-dependent function derived from fitting the intercept vector $b$ as a logarithmic function of PAR. Here, we found that $g_{\text {ref }}$ is

$$
\begin{aligned}
g_{\text {ref }}= & 0.0922 \times \log (P A R) \\
& -0.3985 \mu \mathrm{mol} \mathrm{m}^{-2} \mathrm{~s}^{-1}
\end{aligned}
$$

\section{Appendix C: night-time atmospheric stability considerations}

Correcting night-time eddy-covariance fluxes under conditions of low $u *$ with respiration models parameterized using night-time fluxes with high $u_{*}$ is standard eddycovariance methodology (Goulden et al. 1996; Aubinet et al. 2000; Falge et al. 2001a). We conducted a sensitivity analysis on the annual NEE estimate by varying $u_{*_{t}}$ between 0 and 0.3 , and found that NEE did not vary appreciably for $u_{*}$ between 0.12 and 0.18 . Hence, we first filtered the data with $u_{*}=0.12 \mathrm{~m} \mathrm{~s}^{-1}$. NEE is highly sensitive to the $u_{*}$ threshold value chosen ( $u_{*}$; Barford et al. 2001), but the exclusive use of $u_{*}$ has not been examined, and we propose additional meteorological constraints to filters used for night-time eddy-covariance data. Namely, we propose two additional constraints that only accept fluxes when atmospheric stability conditions are near-neutral and when the peak of the source-weight function $\left(x_{\mathfrak{p}}\right)$ lies within the dimensions of the study site 
Fig. 8a-c The effect of $u_{*}$ and atmospheric stability on the calculated night-time $\mathrm{CO}_{2}$ flux footprint. The measurement tower is at the center of the polar plot. Radial lines represent wind directions $\left(0^{\circ}=\right.$ North $)$ and concentric lines represent radial distances from tower $(m)$. a Points represent footprint distances from the tower for all night-time 30-minute runs. b same as a but implementing the friction velocity threshold (i.e., selecting only runs with $u_{*}>u_{*}$, $\left.u_{*}=0.12\right)$. c Same as a but implementing both friction velocity and atmospheric stability thresholds (i.e., selecting runs with $u_{*}>0.12$ and $|(z-d) / L|<\varsigma_{\mathrm{n}}$, $\varsigma_{\mathrm{n}}=0.1$ )

(here $150 \mathrm{~m}$ ). The atmospheric stability parameter in the atmospheric surface layer is defined as $\varsigma=(z-d) / L$, and near-neutral conditions are defined as $|s|<0.1$. We define the near-neutral atmospheric stability threshold of 0.1 to be $\varsigma_{\mathrm{n}}$

The importance of adding $\varsigma_{n}$, to model night-time respiration is illustrated by considering the flux footprint at night for all atmospheric conditions, which exceeds $5 \mathrm{~km}$ (Fig. 8a). Adding $u_{*_{t}}$ alone results in a flux footprint that exceeds $2 \mathrm{~km}$, an order of magnitude larger than the dimensions of our field (Fig. 8b). Filtering with both $u_{*}$ and $\varsigma_{n}$ (Fig. 8c) reduces the night-time flux footprint to $\sim 1,000 \mathrm{~m}$, which still exceeds field dimensions, so we further filter night-time flux measurements when the peak of the source-weight function $\left(x_{\mathrm{p}}\right)$ exceeds $150 \mathrm{~m}$, guaranteeing that measured night-time fluxes originate from our field in a probabilistic sense.

\section{References}

Aubinet M, Grelle A, Ibron A, Rannik Ü, Moncrieff J, Foken T, Kowalski AS, Martin PH, Berbigier P, Bernhofer Ch, Clement R, Elbers J, Granier A, Grünwald T, Morgenstern K, Pilegaard K, Rebmann C, Snijders W, Valentini R, Vesala T (2000) Estimates of the annual net carbon and water exchange of forests: the EUROFLUX methodology. Adv Ecol Res 30:113175
Baldocchi DD, Wilson KB (2001) Modeling $\mathrm{CO}_{2}$ and water vapor exchange of a temperate broadleaf forest across hourly to decadal time scales. Ecol Modell 142:155-184

Baldocchi D, Falge E, Gu L, Olson R, Hollinger D, Running S, Anthoni P, Bernhofer Ch, Davis K, Evans R, Fuentes J, Goldstein A, Katul G, Law B, Lee X, Malhi Y, Meyers T, Munger W, Oechel W, Paw UKT, Peilgaard K, Schmid HP, Valentini R, Verma S, Vesala T, Wilson K, Wofsy S (2001) FLUXNET: a new tool to study the temporal and spatial variability of ecosystem-scale carbon dioxide, water vapor, and energy flux densities. Bull Am Meteorol Soc 82:2415-2434

Barford CC, Wofsy SC, Goulden ML, Munger JW, Pyle EH, Urbanski SP, Hutyra L, Saleska SR, Fitzjarrald D, Moore K (2001) Factors controlling long- and short-term sequestration of atmospheric $\mathrm{CO}_{2}$ in a mid-latitude forest. Science 294:16881691

Bellot J, Sanchez JR, Chirinu E, Hernandez N, Abdelli F, Martinez JM (1999) Effect of different vegetation type cover on the soil water balance in semi-arid areas of southeastern Spain. Phys Chem Earth Part B - Hydrol Oceans Atmos 4:353-357

Bremer DJ, Ham JM (2002) Measurement and modeling of soil $\mathrm{CO}_{2}$ flux in a temperate grassland under mowed and burned regimes. Ecol Appl 12:1318-1328

Bremer DJ, Ham JM, Owensby CE, Knapp AK (1998) Responses in soil respiration to clipping and grazing in a tallgrass prairie. $J$ Environ Qual 27:1539-1548

Bruce JP, Frome M, Haites E, Janzen H, Lal R, Paustian K (1999) Carbon sequestration in soils. J Soil Water Conserv 54:382-389

Brutsaert W (1982) Evaporation into the atmosphere: theory, history and applications. Reidel, Boston

Brutsaert W, Sugita M (1992) Application of self-preservation in the diurnal evolution of the surface-energy budget to determine daily evaporation. J Geophys Res 97:18377-18382

Campbell GS, Norman JM (1998) An introduction to environmental biophysics, 2nd edn. Springer, Berlin Heidelberg New York

Clark KL, Gholz HL, Moncrieff JB, Cropley F, Loescher HW (1999) Environmental controls over net exchanges of carbon dioxide from contrasting Florida ecosystems. Ecol Appl 9:936948

Collatz CJ, Ball JT, Grivet C, Berry JA (1991) Physiological and environmental regulation of stomatal conductance, photosynthesis, and transpiration: a model that includes a laminar boundary layer. Agric For Meteorol 54:107-136

Cowan IR (1977) Stomatal behaviour and environment. Adv Bot Res 4:117-228

Dennis JE Jr (1977) Nonlinear least-squares. In: Jacobs D (ed) State of the art in numerical analysis. Academic Press, pp269-312

Dugas WA, Heuer ML, Mayeux HS (1999) Carbon dioxide fluxes over bermudagrass, native prairie, and sorghum. Agric For Meteorol 93:121-139

Emmerich WE (2003) Carbon dioxide fluxes in a semiarid environment with high carbonate soils. Agric For Meteorol 116:91-102

Everson CS (2001) The water balance of a first order catchment in the montane grasslands of South Africa. J Hydrol 241:110-123

Falge E, Baldocchi D, Olson R, Anthoni P, Aubinet M, Bernhofer C, Burba G, Ceulemans R, Clement R, Dolman H, Granier A, Gross P, Grunwald T, Hollinger D, Jensen NO, Katul G, Keronen P, Kowalski A, Lai CT, Law BE, Meyers T, Moncrieff H, Moors E, Munger JW, Pilegaard K, Rannik Ü, Rebmann C, Suyker A, Tenhunen J, Tu K, Verma S, Vesala T, Wilson K, Wofsy S (2001a) Gap filling strategies for defensible annual sums of net ecosystem exchange. Agric For Meteorol 107:4369

Falge E, Baldocchi D, Olson R, Anthoni P, Aubinet M, Bernhofer C, Burba G, Ceulemans G, Clement R, Dolman H, Granier A, Gross P, Grunwald T, Hollinger D, Jensen NO, Katul G, Keronen P, Kowalski A, Lai CT, Law BE, Meyers T, Moncrieff J, Moors E, Munger JW, Pilegaard K, Rannik Ü, Rebmann C, Suyker A, Tenhunen J, Tu K, Verma S, Vesala T, Wilson K, Wofsy S (2001b) Gap filling strategies for long term energy flux data sets. Agric For Meteorol 107:71-77 
Fang C, Moncreiff JB (2001) The dependence of soil $\mathrm{CO}_{2}$ efflux on temperature. Soil Biol Biochem 33:155-165

Farquhar GD, von Caemmerer S, Berry JA (1980) A biochemical model of photosynthetic $\mathrm{CO}_{2}$ assimilation in leaves of $\mathrm{C}_{3}$ species. Planta 149:78-90

Flanagan LB, Wever LA, Carlson PJ (2002) Seasonal and interannual variation in carbon dioxide exchange and carbon balance in a northern temperate grassland. Glob Change Biol 8:599-615

Frank AB, Dugas WA (2001) Carbon dioxide fluxes over a northern, semiarid, mixed-grass prairie. Agric For Meteorol 108:317-326

Frank AB, Sims PL, Bradford JA, Mielnick PC, Dugas WA, Mayeux HS (2001) Carbon dioxide fluxes over three great plains grasslands. In: Follett RF, Kimble JM, Lal R (eds) The potential of US grazing lands to sequester carbon and mitigate the greenhouse effect. Lewis, Boca Raton, pp167-187

Gill RA, Polley HW, Johnson HB, Anderson LJ, Maherali H, Jackson RB (2002) Nonlinear grassland responses to past and future atmospheric $\mathrm{CO}_{2}$. Nature 417:279-282

Gilmanov TG, Johnson DA, Saliendra NZ (2003a) Growing season $\mathrm{CO}_{2}$ fluxes in a sagebrush-steppe ecosystem in Idaho: Bowen ratio/energy balance measurements and modeling. Basic Appl Ecol 4:167-183

Gilmanov TG, Johnson DA, Saliendra NZ, Akshalov K, Wylie BK (2003b) Gross primary productivity of the true steppe in central Asia in relation to NDVI: scaling up of $\mathrm{CO}_{2}$ fluxes. Environ Manage (in press)

Goulden ML, Munger JW, Fan SM, Daube BC, Wofsy SC (1996) Measurements of carbon sequestration by long-term eddy covariance: methods and a critical evaluation of accuracy. Glob Change Biol 2:169-182

Grace J, Lloyd J, Miranda AC, Miranda H, Gash JHC (1998) Fluxes of carbon dioxide and water vapour over a C-4 pasture in southwestern Amazonia (Brazil). Aust J Plant Physiol 25:519-530

Ham JM, Knapp AK (1998) Fluxes of $\mathrm{CO}_{2}$, water vapor, and energy from a prairie ecosystem during the seasonal transition from carbon sink to carbon source. Agric For Meteorol 89:1-14

Hoff JH van't (1898) Lectures on theoretical and physical chemistry. In: Chemical dynamics part I. Arnold, London, pp224-229

Houghton JT, Ding Y, Griggs DJ, Nouger M, van der Linden PJ, Day X, Maskell K, Johnson CA (eds) (2001) Climate change 2001: the scientific basis. Third assessment report of Working Group I. Cambridge University Press, Cambridge

Hsieh C-I, Katul GG, Chi T (2000) An approximate analytical model for footprint estimation of scalar fluxes in thermally stratified atmospheric flows. Adv Water Resour 23:765-772

Hunt JE, Kelliher FM, McSeveny TM, Byers JN (2002) Evaporation and carbon dioxide exchange between the atmosphere and a tussock grassland during a summer drought. Agric For Meteorol 111:65-82

Jackson RB, Carpenter SR, Dahm CN, McKnight DM, Naiman RJ, Postel SL, Running SW (2001) Water in a changing world. Ecol Appl 11:1027-1045

Jackson RB, Banner JL, Jobbágy EG, Pockman WT, Wall DH (2002) Ecosystem carbon loss with woody plant invasion of grasslands. Nature 418:623-626

Janssens IA, Pilegaard K (2003) Large seasonal changes in Q(10) of soil respiration in a beech forest. Glob Change Biol 9:911-918

Jarvis PG (1976) The interpretation of the variations in leaf water potential and stomatal conductance found in canopies in the field. Philos Trans R Soc Lond B Biol Sci 273:593-610

Katul GG, Oren R, Ellsworth D, Hsieh CI, Phillips N, Lewin K (1997) A lagrangian dispersion model for predicting $\mathrm{CO}_{2}$ sources, sinks, and fluxes in a uniform loblolly pine (Pinus taeda L.) stand. J Geophys Res 102:9309-9321

Katul GG, Ellsworth DS, Lai C-T (2000) Modeling assimilation and intercellular $\mathrm{CO}_{2}$ from measured conductance: a synthesis of approaches. Plant Cell Environ 23:1313-1328

Kelliher FM, Leuning R, Schulze ED (1993) Evaporation and canopy characteristics of coniferous forests and grasslands. Oecologia 95:153-163
Kim J, Verma SB (1991) Modeling canopy stomatal conductance in a temperate grassland ecosystem. Agric For Meteorol 55:149166

Kim J, Verma SB, Clement RJ (1992) Carbon dioxide budget in a temperate grassland ecosystem. J Geophys Res 97:6057-6063

Kirschbaum MUF (2000) Will changes in soil organic carbon act as a positive or negative feedback on global warming? Biogeochemistry 48:21-51

Knapp AK, Smith MD (2001) Variations among biomes in temporal dynamics of aboveground primary productivity. Science 291:481-484

Knapp AK, Conard SL, Blair JM (1998) Determinants of soil $\mathrm{CO}_{2}$ flux from a sub-humid grassland: effects of fire and fire history. Ecol Appl 8:760-770

Lai C-T, Katul GG (2000) The dynamic role of root-water uptake in coupling potential to actual transpiration. Adv Water Res $23: 427-439$

Leuning R (1995) A critical appraisal of a combined stomatalphotosynthesis model for $\mathrm{C}_{3}$ plants. Plant Cell Environ 18:339355

Lloyd J, Taylor JA (1994) On the temperature dependence of soil respiration. Funct Ecol 8:315-323

Long SP, Jones MB, Roberts MJ (eds) (1992) Primary productivity of grass ecosystems of the tropics and sub-tropics. Chapman and Hall, London

Medlyn BE, Dreyer E, Ellsworth D, Forstreuter M, Harley PC, Kirschbaum MUF, Le Roux X, Loustau D, Montpied P, Strassemeyer J, Walcroft A, Wang K (2002) Temperature response of parameters of a biochemically-based model of photosynthesis. II. A review of experimental data. Plant Cell Environ 25:1167-1175

Meyers TP (2001) A comparison of summertime water and $\mathrm{CO}_{2}$ fluxes over rangeland for well watered and drought conditions. Agric For Meteorol 106:205-214

Miranda AC, Miranda HS, Lloyd J, Grace J, Francey RJ, McIntyre JA, Meir P, Riggan P, Lockwood R, Brass J (1997) Fluxes of carbon, water and energy over Brazilian cerrado: an analysis using eddy covariance and stable isotopes. Plant Cell Environ $20: 315-328$

Norman JM, Campbell GS (1989) Canopy structure. In: Pearcy RW, Ehleringer J, Mooney HA, Rundel PW (eds) Plant physiological ecology field methods and instrumentation. Chapman and Hall, New York, pp 301-325

Nouvellon Y, Rambal S, Lo Seen D, Moran MS, Lhomme JP, Bégué A, Chehbouni AG, Kerr Y (2000) Modelling of daily fluxes of water and carbon from shortgrass steppes. Agric For Meteorol 100:137-153

Ojima DS, Dirks BOM, Glenn EP, Owensby CE, Scurlock JO (1993) Assessment of C budget for grasslands and drylands of the world. Water Air Soil Pollut 70:95-109

Oren R, Sperry JS, Katul GG, Pataki DE, Ewers BE, Phillips N, Schäfer KVR (1999) Survey and synthesis of intra- and interspecific variation in stomatal sensitivity to vapour pressure deficit. Plant Cell Environ 22:515-1526

Oren R, Ellsworth DS, Johnsen KH, Phillips N, Ewers BE, Maier C, Schäfer KVR, McCarthy H, Hendrey G, McNulty SG, Katul GG (2001) Soil fertility limits carbon sequestration by forest ecosystems in a $\mathrm{CO}_{2}$-enriched atmosphere. Nature 411:469 472

Parton WJ, Scurlock JMO, Ojima DS, Gilmanov TG, Scholes RJ, Schimel DS, Kirchner T, Menaut JC, Seastedt T, Moya EG, Kamnalrut A, Kinyamario JI (1993) Observations and modeling of biomass and soil organic matter dynamics for the grassland biome worldwide. Glob Biogeochem Cycles 7:785809

Paz A, Neira A, Castelao A (1996) Soil water regime under pasture in the humid zone of Spain: validation of an empirical model and prediction of irrigation requirements. Agric Water Manage 29:147-161

Press WH, Teukolsky SA, Vetterling WT, Flannery BP (1992) Numerical recipes in Fortran. Cambridge University Press, Cambridge 
Raich JW, Potter CS (1995) Global patterns of carbon dioxide emissions from soils. Glob Biogeochem Cycles 9:23-36

Raich JW, Schlesinger WH (1992) The global carbon dioxide flux in soil respiration and its relationship to vegetation and climate. Tellus 44B:81-99

Redmann RE (1978) Seasonal dynamics of carbon dioxide exchange in a mixed grassland ecosystem. Can J Bot 56:1999-2005

Reichstein M, Tenhunen JD, Roupsard O, Ourcival JM, Rambal S, Dore S, Valentini R (2002) Ecosystem respiration in two Mediterranean evergreen holm oak forests: drought effects and decomposition dynamics. Funct Ecol 16:27-39

Ripley EA, Saugier B (1974) Microclimate and production of a native grassland: a micrometeorological study. Oecol Plant 9:333-363

Ripley EA, Saugier B (1978) Biophysics of a natural grassland: evaporation. J Appl Ecol 15:459-479

Rosenzweig C, Tubiello FN, Goldberg R, Mills E, Bloomfield J (2002) Increased crop damage in the US from excess precipitation under climate change. Glob Environ Change 12:197202

Saigusa N, Oikawa T, Liu S (1998) Seasonal variations of the exchange of $\mathrm{CO}_{2}$ and $\mathrm{H}_{2} \mathrm{O}$ between a grassland and the atmosphere: an experimental study. Agric For Meteorol 89:131-139

Sarmiento JL, Wofsy SC (co-chairs) (1999) A US carbon cycle science plan: a report of the Carbon and Climate Working Group. US Global Change Research Program, Washington, D. C.

Scurlock JMO, Johnson K, Olson RJ (2002) Estimating net primary productivity from grassland biomass dynamics measurements. Glob Change Biol 8:736-753

Shaw MR, Zavaleta ES, Chiariello NR, Cleland EE, Mooney HA, Field CB (2002) Grassland responses to global environmental changes suppressed by elevated $\mathrm{CO}_{2}$. Science 298:1987-1990

Sims PL, Bradford JA (2001) Carbon dioxide fluxes in a southern plains prairie. Agric For Meteorol 109:117-134

Suyker AE, Verma SB (2001) Year-round observations of the net ecosystem exchange of carbon dioxide in a native tallgrass prairie. Glob Change Biol 7:279-289

Suyker AE, Verma SB, Burba GG (2003) Interannual variability in net $\mathrm{CO}_{2}$ exchange of a native tallgrass prairie. Glob Change Biol 9:255-265
Tappeiner U, Cernusca A (1996) Microclimate and fluxes of water vapour, sensible heat and carbon dioxide in structurally differing subalpine plant communities in the central Caucasus. Plant Cell Environ 19:403-417

Tjoelker MG, Oleksyn J, Reich PB (2001) Modelling respiration of vegetation: evidence for a general temperature-dependent $\mathrm{Q}_{10}$. Glob Change Biol 7:223-230

Valentini R, Gamon JA, Field CB (1995) Ecosystem gas exchange in a California grassland: seasonal patterns and implications for scaling. Ecology 76:1940-1952

Valentini R, Matteucci G, Dolman AJ, Schulze E-D, Rebmann C, Moors EJ, Granier A, Gross P, Jensen NO, Pilegaard K, Lindroth A, Grelle A, Bernhofer C, Grünwald T, Aubinet M, Ceulemans R, Kowalski AS, Vesala T, Rannik Ü, Berbigier P, Loustau D, Gumundsson J, Thorgeirsson H, Ibrom A, Morgenstern K, Clement R, Moncrieff J, Montagnani L, Minerbi S, Jarvis PJ (2000) Respiration as the main determinant of carbon balance in European forests. Nature 404:861-865

Vörösmarty CJ, Sahagian D (2000) Anthropogenic disturbance of the terrestrial water cycle. Bioscience 50:753-765

Wagai R, Brye KR, Gower ST, Norman JM, Bundy LG (1998) Land use and environmental factors influencing soil surface $\mathrm{CO}_{2}$ flux and microbial biomass in natural and managed ecosystems in southern Wisconsin. Soil Biol Biochem 30:1501-1509

Webb EK, Pearman GI, Leuning R (1980) Correction of flux measurements for density effects due to heat and water vapour transfer. Q J R Meteorol Soc 106:85-100

Wever LA, Flanagan LB, Carlson PJ (2002) Seasonal and interannual variation in evapotranspiration, energy balance and surface conductance in a northern temperate grassland. Agric For Meteorol 112:31-49

White R, Murray S, Rohweder M (2000) Pilot Analysis of Global Ecosystems (PAGE): grassland ecosystems. World Resources Institute, Washington, D.C

Wilsey BJ, Parent G, Roulet NT, Moore TR, Potvin C. (2002) Tropical pasture carbon cycling: relationships between $\mathrm{C}$ source/sink strength, above-ground biomass and grazing. Ecol Lett 5:367-376

Wilson KB, Baldocchi DD (2001) Comparing independent estimates of carbon dioxide exchange over 5 years at a deciduous forest in the southeastern United States. J Geophys Res 106:34167-34178 